\title{
Estimation of carbon sequestration in reclaimed coalmine degraded land dominated by Albizia lebbeck, Dalbergia sissoo and Bambusa arundinacea plantation: a case study from Jharia Coalfields, India
}

\author{
Rimi Das ${ }^{1} \cdot$ Subodh Kumar Maiti ${ }^{1}$
}

Received: 31 December 2015/Revised: 27 April 2016/Accepted: 7 June 2016/Published online: 27 June 2016

(C) The Author(s) 2016. This article is published with open access at Springerlink.com

\begin{abstract}
Reclaimed mined lands provide an excellent opportunity to sequester carbon and combat global warming. Carbon sequestration on reclaimed sites depend on age of reclamation, composition of species, geomining conditions (soil characteristics) and prevailing climate. The aims of the present study were to calculate carbon (C)—stock of biomass of 4 years old plantation (dominated by Albizia lebbeck, Dalbergia sissoo and Bambusa arundinacea), understorey vegetation and litter, soil organic carbon in reclaimed minesoil (RMS) and compare with reference forest site. Allometric equation was used for the estimation of biomass $\mathrm{C}$ stock and found $13.0 \mathrm{Mg} \mathrm{C} \mathrm{ha}^{-1}$ (A lebbeck $7.8 \mathrm{Mg} \mathrm{C} \mathrm{ha}^{-1}$, D sissoo 3.5 $\mathrm{Mg} \mathrm{C} \mathrm{ha}^{-1}$ and B. arundincea $1.2 \mathrm{Mg} \mathrm{C} \mathrm{ha}^{-1}$ ), while stock of understorey vegetation was $0.98 \mathrm{Mg} \mathrm{Cha}^{-1}$. In RMS, C stock was $16.3 \mathrm{Mg} \mathrm{C} \mathrm{ha}^{-1}$, out of which inorganic C contributed $1.7 \mathrm{~g} \mathrm{~kg}^{-1}$ (8\% of total soil C), Coal C $8.7 \mathrm{~g} \mathrm{~kg}^{-1}$ (43\% of total soil C) and biogenic $\mathrm{C} 9.8 \mathrm{~g} \mathrm{~kg}^{-1}$ (49\% of total soil C). Total C stock in reclaimed site was calculated as $30.3 \mathrm{Mg} \mathrm{C} \mathrm{ha}^{-1}$ (equivalent to $111 \mathrm{Mg} \mathrm{CO}_{2} \mathrm{ha}^{-1}$ ). The study concluded that (i) coal $\mathrm{C}$ is responsible for overestimation of $\mathrm{C}$ stock in RMS (ii) Maximun $\mathrm{C}$ stock stored in aboveground biomass component and (iii) reclaimed mined lands will take approximately 17 years to reach the level of $\mathrm{C}$ stock of reference forest site in dry tropical climate.
\end{abstract}

Keywords Coal $\cdot$ Opencast mining $\cdot$ Reclaimed mine soils $\cdot$ Biomass carbon $\cdot$ Carbon sequestration $\cdot$ Carbon stock

\section{Introduction}

Carbon (C) sequestration is defined as "the process of increasing the $\mathrm{C}$ content of a $\mathrm{C}$ pool other than the atmosphere" (IPCC 2000). Terrestrial C sequestration is the process of (i) transforming or transferring atmospheric $\mathrm{CO}_{2}$ through photosynthesis into biomass components such as trees, shrubs, vegetation, and soil organic matter (SOM), and (ii) incorporation of biomass into the soil as humus. This leads to the effective storage of atmospheric $\mathrm{CO}_{2}$ in these biomass components until decomposition of biomass into the soil. Soil contains approximately $75 \%$ of the

Subodh Kumar Maiti

skmism1960@gmail.com

1 Ecological Restoration Laboratory, Department of Environmental Science and Engineering (Centre of Mining Environment), Indian School of Mines, Dhanbad, Jharkhand 826004 , India terrestrial C pool, which is three times more than the amount stored in living plants and hence it plays a vital role in the global C cycling (Schlesinger and Bernhardt 2013).

In India, massive expansion of opencast mines is envisaged by adoption of latest technologies to meet the target and about $90 \%$ of the coal is extracted by the opencast mining. During the process of surface coal mining, vegetation cover is completely stripped, and soils and overburden (OB) rocks are removed to reach the coal-deposit, which generates huge volume of heterogeneous mass, stored as OB dumps (external dumps) or used as backfill materials to fill open cast voids (internal dumping). These OB dumps, initially devoid of soil organic carbon (SOC) and generally reclaimed into a forest land through forestry reclamation approach (FRA) (Zipper et al. 2011; Skousen and Zipper 2014). Establishment of vegetation cover with high biomass production in reclaimed minesoils (RMS) reduces soil degradation and improves SOC with time. During technical reclamation, after dressing the 
surface, topsoil is applied and slope is blanketing with coir mat, and seeded with grass-legume mixture as an initial colonizer to the site (Maiti and Maiti 2015; Xiao et al. 2014). In the top flat surface of the dump, fast growing tree species saplings are planted with addition of topsoil in plantation pits (Maiti and Ghose 2005; Maiti et al. 2007).

Studies across the globe on $\mathrm{C}$ sequestration through reclaimed coal mine soils have received considerable attention in recent past (IPCC 2000; Akala and Lal 2000, 2001; Ussiri and Lal 2005; Sperow 2006; Amichev et al. 2008; Shrestha and Lal 2010; Tripathi et al. 2014, 2016; Das and Maiti 2016). The $\mathrm{CO}_{2}$ sequestration in reclaimed mine sites is calculated by estimating $\mathrm{C}$-stock of biomass (aboveground and belowground), litter and reclaimed minesoils (Fig. 1). The aboveground biomass (AGB) C-stock consists of all living vegetation above the soil, inclusive of stems, stumps, branches, bark, seeds and foliage, while the belowground biomass (BGB) C-stock consists of the biomass contained within live roots. The greatest fraction of total biomass of forests is represented by trees, whereas the other carbon pools (understory, dead wood, litter and BGB) represent only a fraction of the total tree biomass. The understorey was estimated $3 \%$ of AGB, dead wood $5 \%-40 \%$, and fine litters only $5 \%$ of that in the AGB (Brown 1997). Destructive sampling is the most accurate method to estimate C-stock of biomass, whereby vegetation is harvested, dried to a constant mass and the dry-to-wet biomass ratio established and correlated with biomass vis. DBH (Diameter at Breast Height). Two other approaches for estimating the tree biomass are: (a) regression equations or allometric equations which provide estimates of biomass per tree based on three main climatic zones, regardless of species; and (b) the conversion of wood volume to biomass density using biomass expansion factors (Brown et al. 1989; Brown 1997). Allometric equations play important role in accurate estimation of above and belowground biomass stock of tree species based on measured independent variables (like, DBH) (Brown et al. 1989). Allometric equations can be represented in many ways, but the most commonly represented by a linear equation (Dudley and Fownes 1992). However, they may also vary according to diameter classes (in particular for higher diameter classes and for smaller diameter class $<10 \mathrm{~cm}$ ). Hence the biomass estimation also varies according to various factors such as DBH of tree species, stand age of the species and topography. Cairns et al. (1997) formulated regression equations to estimate root biomass based on above-ground biomass carbon in tropical, temperate and boreal forests and found a mean root-toshoot (RS) ratio of 0.26 , ranging between 0.18 and 0.30 and stated that the most of the root biomass (heavy roots $>2 \mathrm{~mm}$ diameter) is close to 20 percent of the total
AGB. According to MacDicken (1997), the ratio of belowground to aboveground biomass in forests is about 0.2 , depending on species.

In India, several authors have published biomass estimations through destructive sampling methods and developed allometric equations for a few tree species $>10 \mathrm{~cm}$ DBH in reclaimed minesoils and forests (Singh and Singh 1995; Lodhiyal et al. 2002). Amichev et al. (2008) also derived allometric equations for the estimation of biomass in reclaimed minesoil of Midwestern and Appalachian coalfields of USA.

Litter accumulation is also an important parameter for consideration in the $\mathrm{C}$ sequestration study. Litterfall consists of dead plant material, such as leaves, bark, seeds, logs, or reproductive organs, and twigs that has fallen to the ground. Litterfall depends upon type of tree species, plant debris, the type of ecosystem (forest or grassland) and various factors. For example forest ecosystem accounts for $70 \%$ of litterfall (leaf), but woody litter increase with forest age, however in grassland ecosystem, the annual litterfall is very low due to very little aboveground perennial tissue (Lonsdale 1988).

Mining and associated disturbances disrupt the SOC equilibrium relationship, causing severe losses of SOC due to unfavorable physico-chemical characteristics, leading to a $\mathrm{C}$ deficit and poor conditions for both plant and microbial growth and SOC. Revegetation and proper management practices help to regain the lost $\mathrm{C}$; improve the soil quality and restore the SOC by reabsorbing it from the atmosphere (Lal and Bruce 1999). Several researchers in USA studied $\mathrm{C}$ accumulation in minesoils which were reclaimed to cropland, pasture or forest (Akala and Lal 2000, 2001; Amichev et al. 2008; Sperow 2006). Total soil C (TSC) content in reclaimed or biologically restored minesoils consist of three types of pools namely (i) soil inorganic $\mathrm{C}$ (SIC), (ii) geogenic $\mathrm{C}$ (coal-C or fossil C) and (iii) biogenic C (plant derived recent SOC) (Ussiri and Lal 2008). Sources of SIC are parent rock of overburden materials which consists of carbonates or calcite and dolomite in significant concentrations. "Geogenic C" in minesoils originates from the incorporation of coal particles or coal dust during overburden removal, coal mining and reclamation operations, while "biogenic C" originates from recent biological inputs. Microbial decomposition of biogenic $\mathrm{C}$ sources (litter) along with different pedogenic process leads to their mixing with coal $\mathrm{C}$ and also the humus fraction. The stable fractions of "biogenic C" such as the humus and mineralizable fractions are responsible for maintaining long term $\mathrm{CO}_{2}$ sequestration as it controls the SOC pool. However, standard procedures for quantifying SOC concentrations in RMS cannot distinguish coal $\mathrm{C}$ from biogenic $\mathrm{C}$ due to presence of large amount of coal carbon. This leads to overestimation of $\mathrm{C}$ pools and 


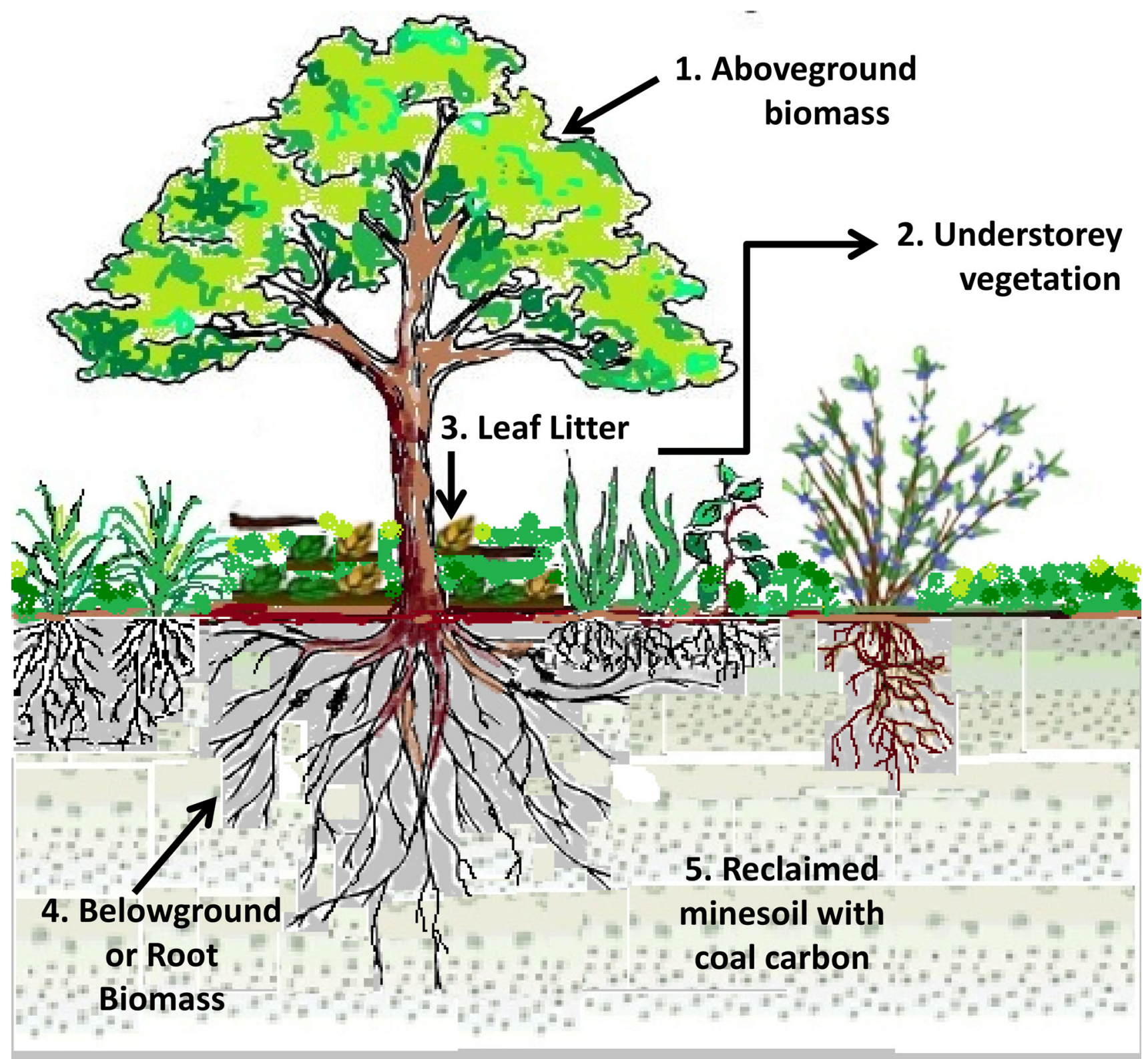

Fig. 1 Schematic diagram showing distrribution of carbon-stock stored in reclaimed coalmine site ( 1 to 5 ) and summation of all components gives $\mathrm{CO}$ seqquestration values (Million gram carbon per hectar, $\mathrm{Mg} \mathrm{C} \mathrm{ha}{ }^{-1}$ ). 1 Aboveground biomass, 2 and 3 Litterfall and understorey vegetation which includes shrubs, herbs, 4 Root biomass and 5 Soil organic carbon in reclaimed minesoils intermixed with coal carbon

sequestration rates, which must be corrected (Ussiri et al. 2014),

Scanty literature is available on $\mathrm{C}$ sequestration potential in RMS of India inspite of plentiful reports available worldwide. Direct tree harvest data is difficult to obtain and very less numbers of studies are available in the literature. In the present study, non harvest technique and allometric equations were used to estimate biomass and total carbon sequestered by different plant species in the reclaimed site. The aims of the present study are: (i) to estimate biomass $\mathrm{C}$ stock by using allometric equation; (ii) to estimate $\mathrm{C}$ stock of understorey vegetation, (iii) to study accumulation of $\mathrm{C}$ stock in mine soil and (iv) to study the distribution of sequestered C in different components of RMS (SOC or biogenic carbon; after removal of coal and inorganic carbon) and, (iv) to estimate rate of $\mathrm{C}$ sequestration and predict recovery of $\mathrm{C}$ stock in reclaimed mine soil to reference forest site.

\section{Materials and methods}

\subsection{Location of study area}

Carbon sequestration potential study was carried in a ecologically restored coalmine overburden dumps located 
in the Damoda colliery, Barora area, Jharia Coalfields (Bharat Coking Coal Limited, BCCL), Jharkhand, India. The Jharia coalfields falls between latitudes $23^{\circ} 39^{\prime}-$ $23^{\circ} 48^{\prime} \mathrm{N}$ and longitudes $86^{\circ} 11^{\prime}-86^{\circ} 27^{\prime} \mathrm{E}$ covering an area of $450 \mathrm{~km}^{2}$. The site was located in the western part of Jharia coalfield which is characterized for the long history of land degradation, hostile climatic conditions, different tree species composition and slow succession process. The climate of the study area is dry tropical and characterized by hot and dry summer (March to June), rainy (July to October) and winter season (November to February). The average annual relative humidity is about $63 \%$. In summer months, the relative humidity (RH) varies between $32 \%$ and $72 \%$. The temperature rises up to 42 to $46{ }^{\circ} \mathrm{C}$ on some summer days. In winter, the maximum and minimum temperature is 22 and $8{ }^{\circ} \mathrm{C}$ respectively, and sometimes drops down to $5-7{ }^{\circ} \mathrm{C}$, in December and January, are the coldest months. Dust storms are common in dry season (May and June) before the onset of monsoon with increase in temperature and wind speed in the afternoon coupled with low humidity. The area receives annual rainfall of about 1140-1700 mm (average: $1306 \mathrm{~mm}$ ), out of which $75 \%-80 \%$ of the annual rainfall occurs during the three months of June to September with smaller amounts during winter months. Number of rainy days in a year is about 100 days and the maximum rainfall occurring in the month of August. The wind speed of the area varies from 1.5 to $2.8 \mathrm{~ms}^{-1}$.

The mining has been carried out by shovel-dumper combination and carbon sequestration study was carried out in a backfilled, lavelled OB dumps with presence of large rocks at surface. The rock types consist of sandstone $(45 \%)$, carbonaceous shale $(20 \%)$, intermixed shale and sandstone $(16 \%)$, Jhama (heat affected coal) with mica peridotite (3\%), subsoil (4\%) and coal (12\%) (Chandra 1992). The chemical composition of the rocks is very important because significant quantities of various plant nutrients are usually made available during the weathering process (Coppin and Bradshaw 1982).

The total study area was approximately 4 ha $\left(40000 \mathrm{~m}^{2}\right)$ and the age of the entire restored site is 4 years. Location of study area is shown in Fig. 2. A 3-tier plantation consisting of grasses, shrubs and several tree species (native to the nearby forest) were raised before the onset on monsoon in the year 2011 by the BCCL in association with Forest Department to re-establish forest vegetation in the overburden dump. For raising tree species, saplings were planted in the plantation pits $(30 \mathrm{~cm} \times 30 \mathrm{~cm} \times 30 \mathrm{~cm})$ with the addition topsoil with weathered OB materials (soil: spoil; 1:4). Tree saplings used in the restoration purposes, are characterized by low in stature, water and nutrient demands, deciduous, and has economic and ecological values with high survival rate (Fig. 3). Figure 4 shows the arising of tender shoots from the node of bamboo culms after the propagation at initial stage of reclamation at the site. Figure 5 shows growing tree species (Albizia lebbeck), a shrub species (Z. oenoplia) and bamboo clumps at initial stage of plantation. The vegetation was protected from cattle by a boundary wall made of stones and boulders. A cemented signboard showing the type and no. of species planted is placed near the boundary wall (Fig. 6). During summer, trees were watered and additional soil was applied in the plantation pits of new growing trees or saplings to ameliorate the rhizospheric temperature and prevent them from dying. Bamboo, Kala siris (Abizzia lebbeck), Safed Siris (A. procera) and Shisham (Dalbergia sissoo) were the dominating species in the site along with Amla (Phyllanthus emblica) and grasses Dennanath (Pennisetum pedicellatum), Kash (Saccharam munja, S. spontaneum). The dense growth of all these tree species and undergrowth of grasses and shrubs established complete 3-tier vegetation (Fig. 7)

\subsection{Vegetation characteristics of the study area}

The study area consists of 3-tier plantation of grasses, shrubs and several fast growing deciduous tree species (Table 1). Three random quadrats of size $10 \mathrm{~m} \times 10 \mathrm{~m}$ (each quadrat of $100 \mathrm{~m}^{2}$ area) (Fig. 8) were laid down and no. of trees of a particular species in each quadrat was recorded. Total 13 species were present in the quadrate including different grasses, bamboo and saplings of trees, out of which some of the saplings constituted Phyllanthus emblica, Albizia lebbeck, D. sissoo, Terminalia arjuna, Lannea coromandelica, and others. Bamboo clumps were recorded separately since the bamboo plantation dominated in the study site for calculation of density $\mathrm{ha}^{-1}$. The girth of each tree species was measured at the height of $1.37 \mathrm{~m}$ above the ground level (i.e., DBH). The relative density of tree species with height $>1.5 \mathrm{~m}$ and DBH $>3 \mathrm{~cm}$ was calculated separately and the saplings height $<1.5 \mathrm{~m}$ and DBH $<3 \mathrm{~cm}$ were not considered for carbon sequestration study.

Two dominant tree species, Albizia lebbeck (58\%) and Dalbergia sissoo (33\%) together constitute $90 \%$ of total plants population followed by Phyllanthus emblica (4\%), Mitragyna parviflora (2\%), Syzizium cumini (1\%) and Ziziphus oenoplia (1\%). Relative distribution of tree species in reclaimed site is shown in Fig. 9. Sixty one nos of bamboo clumps were observed in the three quadrats. Therefore the density of bamboo clumps was calculated as 2033 clumps ha ${ }^{-1}$; whereas the tree density was 2500 trees $\mathrm{ha}^{-1}$. 


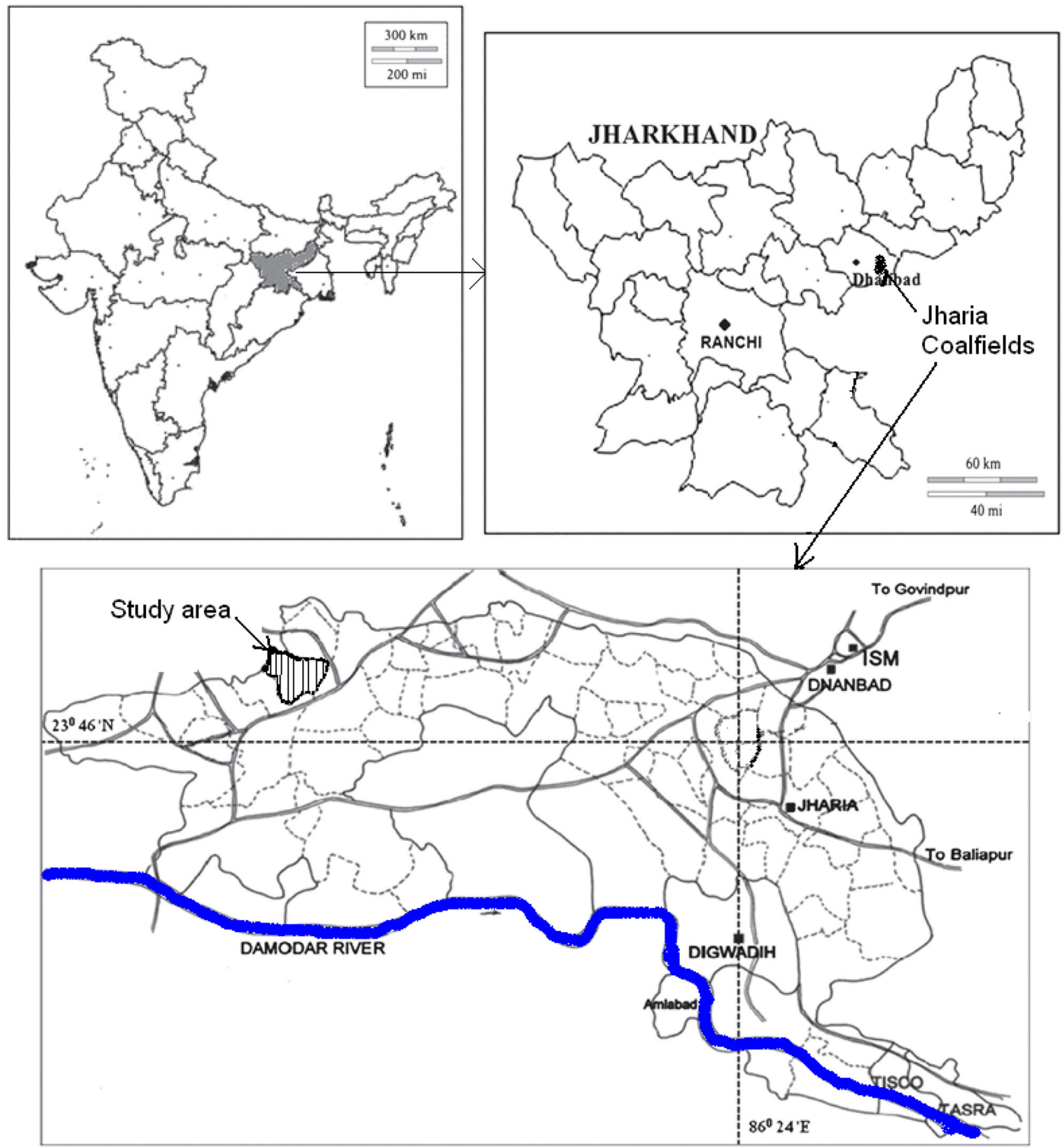

Fig. 2 Location map of study area

\subsection{Reclaimed minesoil sampling and analysis}

Sampling sites were selected underneath the canopy of different tree species A. lebbeck, B. monosperma and bamboo plantation. Total 5 replicates of minesoil samples were randomly collected by laying metal quadrat of $50 \mathrm{~cm} \times 50 \mathrm{~cm}$ using the soil corer at $0-15 \mathrm{~cm}$ depth after the removal of litter layer (if any). Samples were properly packed in air tight sampling bags and brought carefully to laboratory for physical and chemical analysis.

Separate soil core were also collected with corer $(15 \mathrm{~cm}$ height) for the measurement of bulk density at these sites. The soil samples were air dried for a week, crushed lightly by using mortar and pestle to remove the soil particles 


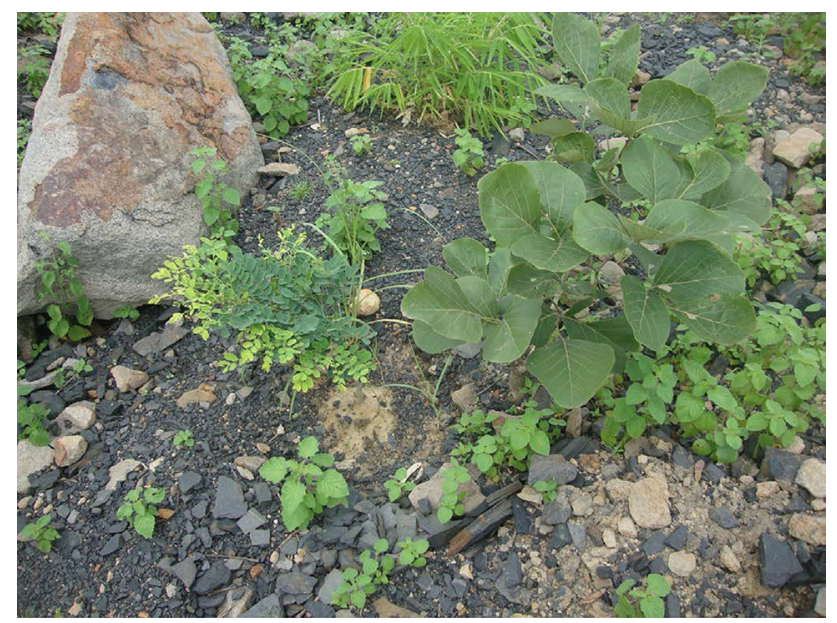

Fig. 3 Initial stage of establishment of tree saplings of Safed Siris ( $A$. procera) by pit plantation. Natural colonisation of Palash (Butea monosperma) on the site

sticking to the non soil particles, followed by sieving through a 2-mm sieve to separate the soil and non soil parts, reweighted to record the proportion of soil fraction ( $<2 \mathrm{~mm}$ size), labeled and kept in air tight sampling bags for further analysis.

The field moisture content of fresh soil was determined by gravimetric method and bulk density was determined by core method (dividing the oven dried mass of soil by the volume of the sample) (Maiti 2013) and corrected for gravel content. The paste $\mathrm{pH}$ and electrical conductivity (EC) was determined in soil: water ratio $(1: 1 ; \mathrm{w} / \mathrm{v})$ suspension with a $\mathrm{pH}$ meter and Conductivity meter respectively (McLean 1982). Soil organic carbon was estimated by rapid dichromate oxidation technique (Nelson and Sommers 1996), available nitrogen by the alkaline potassium permanganate method (Subbiah and Asija 1956), available phosphorus by Bray's method (Bray and Kurtz 1966).

\subsection{Estimation of inorganic, biogenic and coal carbon in reclaimed mine soil (RMS)}

In reclaimed mine soil, the fraction of inorganic $\mathrm{C}$, biogenic $\mathrm{C}$ (labile and stable) and coal $\mathrm{C}$ was determined by the methods suggested by Ussiri and Lal (2008), Chaudhuri et al. (2013) and Das and Maiti (2016). Total soil carbon (TSC) was determined in the CHNS elemental analyser (model: Euro EA) using CRM soil \# 3 as a standard reference material after the sieving through the RMS samples $<250 \mu$ sieve size. The soil was pretreated with $1 \mathrm{M} \mathrm{HCl}$, and loss of weight gives amount of inorganic $\mathrm{C}(\mathrm{IC})$.

$$
\begin{aligned}
\text { Inorganic } \mathrm{C}(\%)= & \mathrm{TSC}(\%) \\
& -\mathrm{TSC}(\%) \text { after } 1 \mathrm{~N} \mathrm{HCl} \text { treatment }
\end{aligned}
$$

Biogenic C $(\%)=\operatorname{TSC}(\%)-($ Coal C $\%+$ IC $\%)$

\subsubsection{Estimation of $C$ stock in reclaimed minesoil}

The estimation of carbon sequestration is based on soil organic carbon (SOC) $(\%)$, corrected bulk density $\left(\mathrm{g} \mathrm{cc}^{-1}\right)$ and depth $(\mathrm{m})$ of soil. The SOC sequestration potential for RMS in mine soil samples is estimated using the following equation (Lal et al. 1998):

$$
\begin{aligned}
\mathrm{Mg} \mathrm{C} \mathrm{ha} & -1= \\
& {\left[\% \mathrm{C} \times \text { Corrected } \mathrm{B}_{\mathrm{d}} \times \mathrm{d}(\mathrm{m})\right.} \\
& \left.\times 10^{4} \mathrm{~m}^{2} \mathrm{ha}^{-1}\right] / 100
\end{aligned}
$$

where $\mathrm{Mg} \mathrm{C} \mathrm{ha}{ }^{-1}$ is the mega grams $\mathrm{C}$ per hectare $\left(1 \mathrm{Mg}=10^{6}\right), \mathrm{B}_{\mathrm{d}}\left(\mathrm{Mg} \mathrm{m}^{-3}\right)$ is the corrected soil bulk density (Mega gram per cubic meter), d soil depth (m), and $\% \mathrm{C}$ is the biogenic carbon fraction in RMS as $\%$.

Corrected soil bulk density was determined after removal of coarse fraction ( $>2 \mathrm{~mm}$ sieve size) from the sample.

\subsection{Collection of understorey vegetation and litter and estimation of $\mathrm{C}$ stock}

Understorey vegetation (grass, herbs, creepers, shrubs) and dry leaf litter accumulated underneath the canopy of different tree species (D. sissoo, Albizzia spp.) and bamboo (B. arundinacea) were collected within the metal quadrat $50 \mathrm{~cm} \times 50 \mathrm{~cm}$ (Fig. 10a). In the RMS, understorey vegetation consists of dominant grass species $P$. pedicellatum, C. ciliaris, C. setigerus, etc. and shrubs (Eupatorium, Lantata etc.) (Figure 10b). Total 5 replicate of samples were collected from the study site. Samples were dried in an oven at $80{ }^{\circ} \mathrm{C}$ to constant weight to obtain the moisture free dry weight as followed by others (Karu et al. 2009; Singh et al. 2011) and expressed as $\mathrm{Mg} \mathrm{ha}^{-1} \mathrm{C}$ stock was calculated by multiplying a factor 0.4 assuming $40 \%$ carbon present in the litter.

\subsection{Estimation of biomass $\mathrm{C}$ stock}

(a) Calculation of above ground biomass The DBH of individual tree species were divided according to their DBH classes (like, 3-5, 5-7, 7-9, 9-11, $11-13 \mathrm{~cm})$. In the present study, non-destructive method of estimation of AGB was used. Mean DBH in each diameter class of individual tree species was used to calculate the AGB per tree (in $\mathrm{kg}$ ) following regression equation, proposed for dry forest in India 

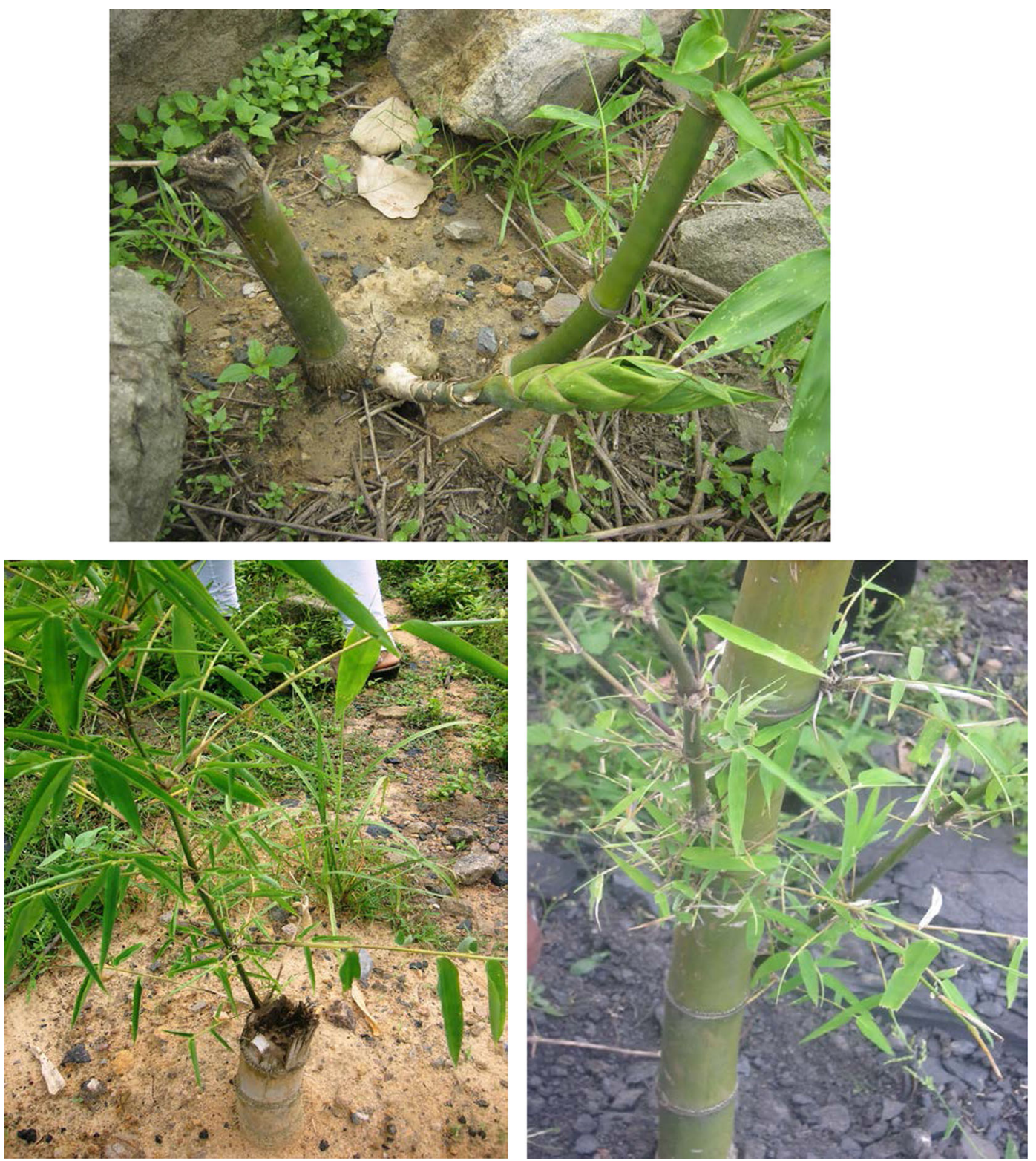

Fig. 4 Tender shoots arising from the node of bamboo culms, which was planted during initial stage of reclamation

with rainfall $>900 \mathrm{~mm}$ year ${ }^{-1}$ (Brown et al. 1989; Brown 1997):

$\mathrm{AGB}=\exp \{-1.996+2.32 \times \ln (\mathrm{D})\}$

where AGB is the aboveground biomass $(\mathrm{kg})$ and $\mathrm{D}$ is the mean diameter at breast height $(\mathrm{DBH})$ of each tree species in each diameter class $(\mathrm{cm})$.

The average AGB multiplied to the tree density per hectare in the diameter classes to convert $\mathrm{Mg} \mathrm{ha}^{-1}$.

(b) Calculation of below ground biomass (BGB): In the present study $20 \%$ of total above ground biomass was considered for the calculation of root biomass (MacDicken 1997). Several studies assumed $25 \%$ of above ground biomass as the root biomass for hardwood species (IPCC 2006). Although there are limitations of using a constant factor for calculation of root biomass (Brown et al. 1989; Cairns et al. 1997), IPCC has proposed this method of estimating root biomass for reporting carbon stocks. Tree specific factors are available, but such factors vary with the age of the tree as well as with the soil characteristics (Brown et al. 1989). The use of constant factor may over/under estimate the total C stock (Cairns et al. 1997). Most of the research work revealed that AGB is strongly correlated with tree diameter (Brown et al. 1989). Also, it is accepted that simple model with only diameter as input is a good estimator of aboveground biomass. 

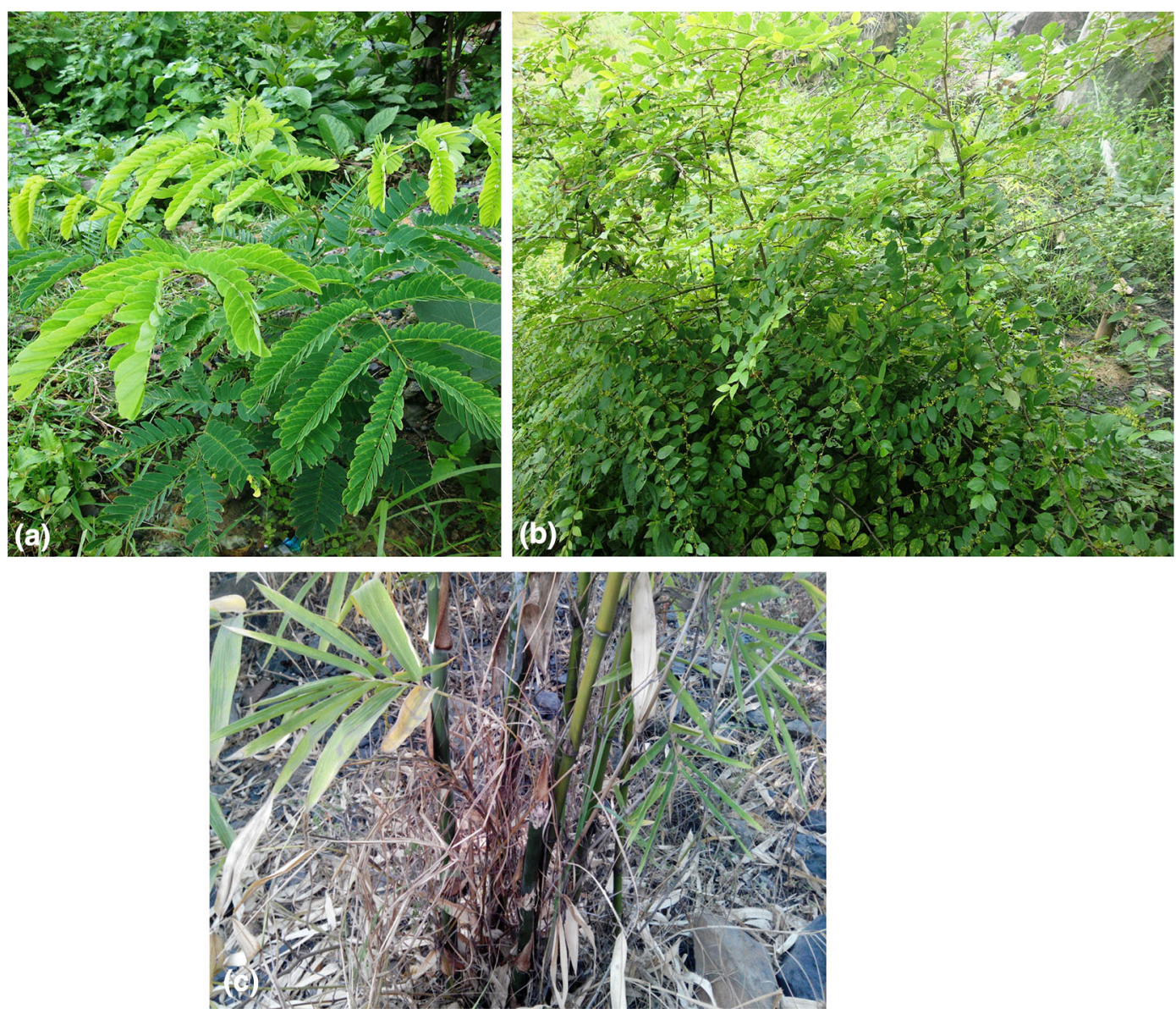

Fig. 5 Growth of vegetation cover in the reclaimed site a Albizia lebbeck (Siris tree), b Ziziphus oenoplia (Wild jujube, a naturally colonizing shrub), c Bambusa tudla (Timber bamboo)

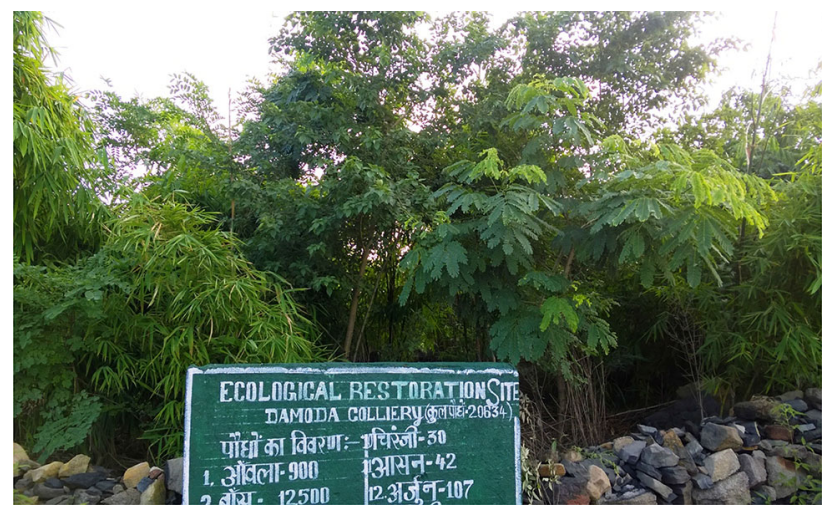

Fig. 6 Outside view of the reclaimed site showing different tree species; boundary wall and board indicating types and no. of species planted

Below ground biomass $\left(\mathrm{Mg} \mathrm{ha}^{-1}\right)$

$=$ Average aboveground biomass $\left(\mathrm{Mg} \mathrm{ha}^{-1}\right)$ $\times 0.2$.

(c) Estimation of total biomass $\left(\mathrm{Mg} \mathrm{ha}^{-1}\right)=\mathrm{AGB}+$ BGB

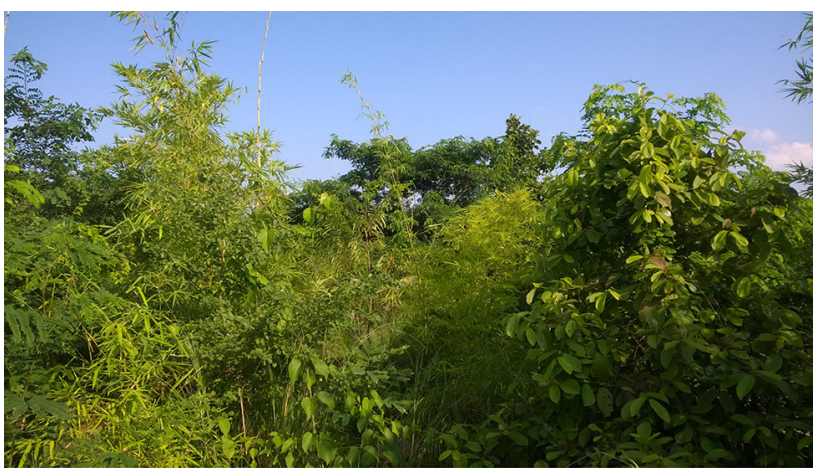

Fig. 7 3-Tier vegetation established in the reclaimed site

(d) Estimation of bamboo biomass: In this study $\mathrm{C}$ stock of bamboo plantation was calculated by considering the work of Singh and Singh (1999).

(e) Estimation of biomass $C$ stock The amount of carbon sequestered was calculated by reducing the biomass yield to its $50 \%$ as per the guidelines of IPCC (2006). Hence biomass value was converted to 
Table 1 Type of vegetation growing in Damoda reclaimed site

\begin{tabular}{|c|c|c|c|}
\hline $\begin{array}{l}\text { S } \\
\text { no. }\end{array}$ & Scientific name (Family) & Common name & Remarks \\
\hline 1. & Albizia lebbeck Benth. (Fabaceae) & Silk flower (Siris) & $\begin{array}{l}\text { Fast growing, medium-large tree, self-regenerated, } \\
\text { common }\end{array}$ \\
\hline 2. & Alstonia scholaris (Linn.) R. Br. (Apocynaceae) & Devil tree (Chatim) & Small- medium size tree, poor growth \\
\hline 3. & Azadirachta indica A. Juss. (Meliaceae) & Margosa(Neem) & Large tree, native, poor growth \\
\hline 4. & Bauhinia variegate Linn. (Cesalpineae) & Bahunia & Medium size tree, not very common \\
\hline 5. & Butea monosperma L. (Fabaceae) & $\begin{array}{l}\text { Flame of the forest } \\
\text { (Palash) }\end{array}$ & Very common, grow naturally in reclaimed site \\
\hline 6. & Dalbergia sissoo Roxb. (Fabaceae) & Sissoo (Sisham) & $\begin{array}{l}\text { Medium size tree, native, very common, luxuriant } \\
\text { growth }\end{array}$ \\
\hline 7. & Bambusa tulda Roxb. (Poaceae) & Indian timber bamboo & Common in reclamation site \\
\hline 8. & Bambusa arundinacea (Retz.) Willd. (Poaceae) & Spiny bamboo & Common in reclamation site \\
\hline 9. & Ficus infectoria (Miq.) Domin. (Moraceae) & White Fig (Pakur) & Large tree, naturally colonise on reclaimed site \\
\hline 10. & $\begin{array}{l}\text { Lannea coromandelica (Houtt.) Merr. } \\
\text { (Anacardiaceae) }\end{array}$ & Indian ash tree (Doka) & Infrequent, naturally colonize \\
\hline 11. & Matragyna perviflora (Roxb.) Korth (Rubiaceae) & Kairn (Gulikadam) & Small- medium size tree, naturally colonize \\
\hline 12. & Melia azedarach L. (Meliaceae) & Persian lilac (Bakain) & Medium size tree, common in dump reclamation \\
\hline 13. & Phyllanthus emblica L. (Phyllanthaceae) & Indian gooseberry & Medium size tree, common, poor growth \\
\hline 14. & Pongamia pinnata Pierre. (Fabaceae) & Indian beech (Karanja) & Medium- large tree, common in dump reclamation \\
\hline 15 . & Syzygium cumini (L.) Skeels (Myrtaceae) & Java plum & Medium size free tree, evergreen \\
\hline 16. & Ziziphus oenoplia (L.) Mill. & Wild jujube (Wild ber) & Evergreen shrub, spreading crown, self colonize \\
\hline
\end{tabular}

Grass species Pennisetum pedicellatum (Dennanath); Saccharam munja, S. spontaneum (Kans); Cenchrus ciliaris (Sui grass); C. setigerus (Dhaman grss); Cynodon dactylon (Doob)

Others Hemidesmus indicus (L.) R.Br. (common creeper, Asclepediaceae), Tephrosia purpurea (L.) Pers. (small shrubs, Fabaceae)

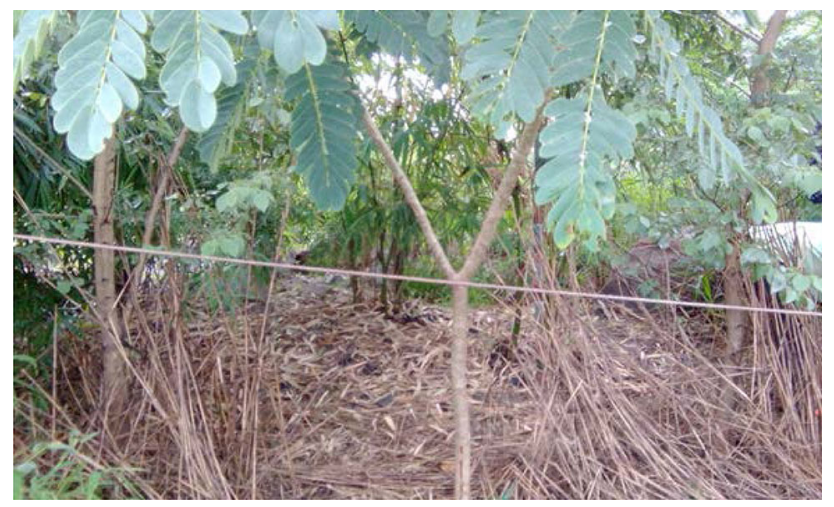

Fig. 8 Portion of quadrant sampling (shown by the rope) in the reclaimed site showing growth of Albizzia lebbek (kala siris), Bamboo and other tree species. Accumulation of litter at the floor consists of dry leaves and annual shrubs (Eupatorium)

carbon stocks by multiplying a factor 0.5 and expressed as $\mathrm{Mg} \mathrm{C} \mathrm{ha}^{-1}$.

\subsection{Estimation of total $\mathrm{C}$ stock and $\mathrm{CO}_{2}$ sequestration in reclaimed site}

In RMS, there are three potential $\mathrm{C}$ sequestration pools, mainly: (i) above and below ground tree biomass, (ii)

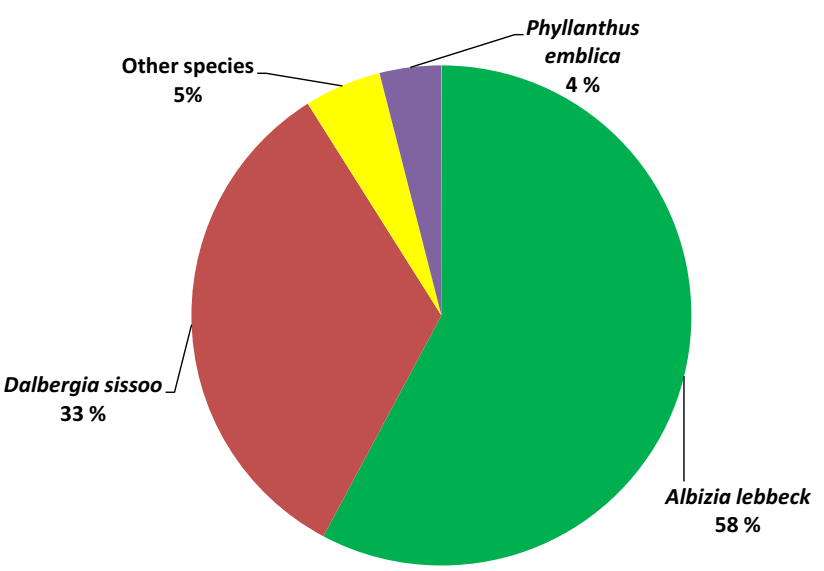

Fig. 9 Relative distribution of tree species in reclaimed site (others species - Alstonia scholaris, Mitragyna parviflora, Syzygiumcumini and Ziziphus oenoplia)

understorey vegetation and litter layer, and (iii) soil organic matter (SOM). Terrestrial plants can sequester carbon through photosynthesis which is stored in various aboveground (leaf, coarse woody material, branch, and logs) and belowground (live and dead roots, and SOM) biomass. This carbon is then transformed from live to dead organic matter 

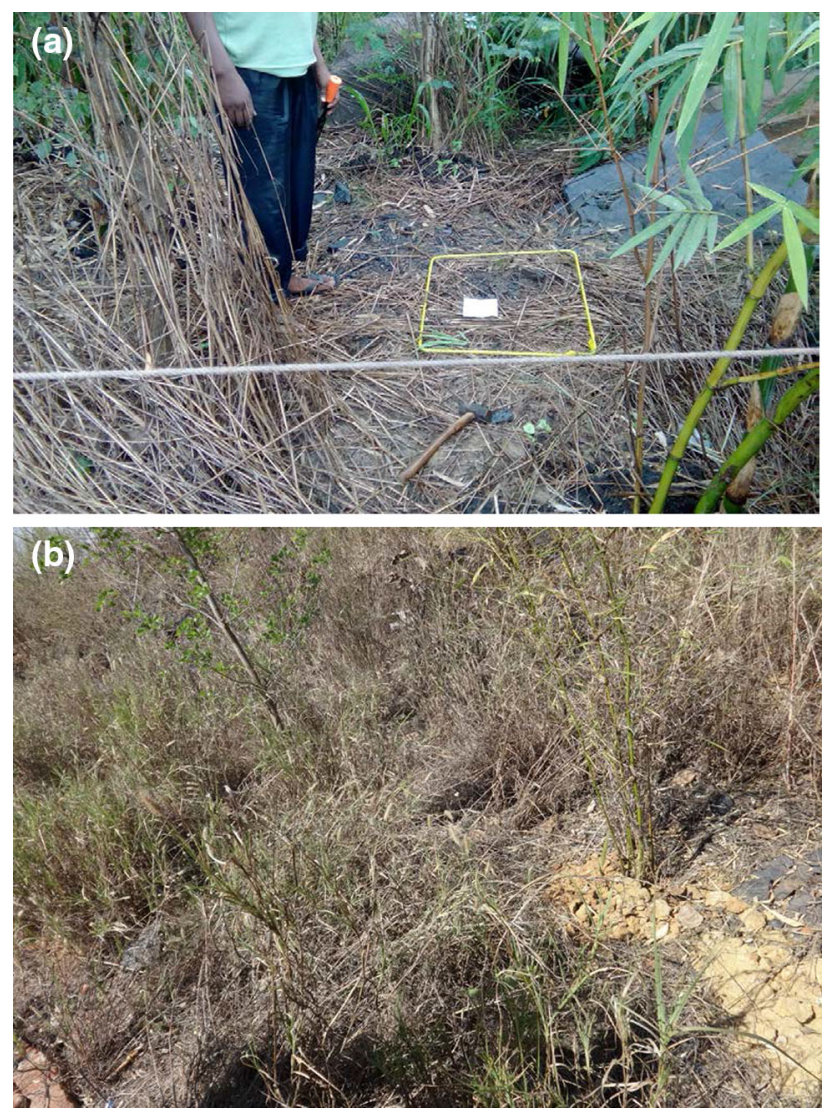

Fig. 10 a Close of view of quadrat sampling for litter collection $(50 \mathrm{~cm} \times 50 \mathrm{~cm})$ taken within the sampling plot $(10 \mathrm{~m} \times 10 \mathrm{~m})$. b Observed dried mulch of Eupatorium and other shrubs and grasses in the reclaimed site

by decomposition via microbes. Different tree species have different degree of influence on $\mathrm{C}$ pool in RMS due to variation in growth characteristics. Thus, the total $\mathrm{C}$ pool can be assessed by adding following components of an ecosystem (Shrestha and Lal 2010):

(a) Sum of Aboveground biomass (AGB) and belowground biomass (BGB) C-pool (CPool (AGB+BGB)

(b) Understorey and litter $\mathrm{C}$ stock (C Pool $\mathrm{UL}$ )

(c) SOC at 0 to $15 \mathrm{~cm}$ depth (C Pool soil 0-15 cm)

$$
\begin{aligned}
\text { Eco C Pool }= & \text { C Pool } \\
& + \text { C Pool }_{\text {soil }(0-15 \mathrm{~cm})}
\end{aligned}
$$

where Eco C Pool is the total ecosystem C stock ( $\mathrm{Mg}$ $\mathrm{C} \mathrm{ha}^{-1}$ ).

Total $\mathrm{C}$ stock is converted to $\mathrm{CO}_{2}$ equivalent by multiplying a factor of 3.67 (by 44/12 ratio). Carbon sequestration rate $\left(\mathrm{Mg} \mathrm{C} \mathrm{ha}^{-1}\right.$ year $\left.^{-1}\right)$ is calculated by dividing total $\mathrm{C}$ stock in RMS ( $\left.\mathrm{Mg} \mathrm{C} \mathrm{ha}^{-1}\right)$ with the age of the dump.

\section{Results and discussion}

\subsection{Physico-chemical characteristics of reclaimed mine soil}

Physico-chemical characteristics of reclaimed mine soil (RMS) significantly influence vegetation growth and accumulation of $\mathrm{C}$ stock. Generally mine soil is characterized with high stone content, lesser soil forming materials, low water holding capacity, low soil organic matter and humus, lower plant available nitrogen and phosphorous (Maiti 2013). Physico-chemical characteristics of reclaimed mine sites and reference forest site are given in Table 2. Soil fraction in RMS found $62 \%$, which was significantly lower than reference forest site $(81 \%)$, while non-soil or coarse fraction ( $>2 \mathrm{~mm}$ size) were found double than reference site. Higher coarse fraction in RMS attributed due to nature of mining, characteristics of rocks, measures taken during technical reclamation and amount of top soil application. However, it was also reported as high as $80 \%-85 \%$ due to geo-mining conditions in most of the reclaimed coalmine overburden dumps (Maiti and Saxena 1998). Excessive amount of coarse fragments limit the fine earth volume required for root proliferation, water-holding capacity, and long-term nutrient availability of plants (Mukhopadhyay et al. 2013; Maiti 2013). It also reduces with time in surface horizons due to weathering processes (Haering et al. 1993; Johnson and Skousen 1995). Corrected bulk density was found $1.12 \mathrm{~g} \mathrm{cc}^{-1}$ (corrected by subtracting courser fraction for soil), which is lower than reference site. Higher values of bulk densities $\left(1.67 \mathrm{~g} \mathrm{cc}^{-1}\right)$ in reclaimed dumps were reported, which is caused due to compaction and lack of organic matter (Barnshiel and Hower 1997; Maiti 2007; Kumar et al. 2015). New mine soils had a slightly higher bulk density than the native soils due to the differences in mining method rather than pedogenic processes. The bulk density decreased with increase in age of reclamation, which is due to root system development, addition of biomass, and improvement in soil structure (Mukhopadhyay et al. 2014). $\mathrm{Bi}$ and Zhang (2014) also reported that soil bulk density of surface soil decreased and soil porosity and field capacity increased after afforestation in coal mining subsidence land. Akala and Lal (2001) also reported that growth and development of roots over time incorporates soil organic carbon and loosens up the soil, thus decreasing soil bulk density. The field moisture content in the RMS was lower (4.7\%) compared to forest site $(7.7 \%)$. Lower moisture content in RMS depends on the time of sampling, height of dump, stone content, soil texture, amount of organic carbon, and litter layer on dump surface (Mukhopadhyay and Maiti 2011). pH of the mine soil mainly depends on the 
Table 2 Physsico-chemical characteristics of reclaimed minesoils $(\mathrm{n}=5)$

\begin{tabular}{|c|c|c|}
\hline Parameter & Reclaimed mine soil & Reference forest site \\
\hline Soil fraction $(<2 \mathrm{~mm}$ size $) \%$ & $\begin{array}{l}61.90 \pm 11.89^{\mathrm{a}} \\
(46.78-74.75)\end{array}$ & $\begin{array}{l}80.62 \pm 5.42 \\
(75.3-87.4)\end{array}$ \\
\hline Non-Soil fraction (>2 mm size) $\%$ & $\begin{array}{l}38.10 \pm 6.75 \\
(24.25-53.22)\end{array}$ & $\begin{array}{l}19.40 \pm 2.98 \\
(15.6-28.2)\end{array}$ \\
\hline Corrected Bulk Density $\left(\mathrm{g} \mathrm{cc}^{-1}\right)$ & $\begin{array}{l}1.12 \pm 0.05 \\
(1.02-1.16)\end{array}$ & $\begin{array}{l}1.34 \pm 0.06 \\
(1.23-1.40)\end{array}$ \\
\hline $\mathrm{pH}(1: 1 ; \mathrm{w}: \mathrm{v})$ & $\begin{array}{l}7.27 \pm 0.49 \\
(6.78-7.85)\end{array}$ & $\begin{array}{l}5.92 \pm 0.19 \\
(5.52-6.32)\end{array}$ \\
\hline $\mathrm{pH}(1: 2.5 ; \mathrm{w}: \mathrm{v})$ & $\begin{array}{l}7.41 \pm 0.54 \\
(6.89-8.01)\end{array}$ & $\begin{array}{l}6.25 \pm 0.42 \\
(5.95-6.40)\end{array}$ \\
\hline $\mathrm{EC}(1: 1 ; \mathrm{w}: \mathrm{v})\left(\mathrm{dS} \mathrm{m}^{-1}\right)$ & $\begin{array}{l}0.182 \pm 0.06 \\
(0.10-0.26)\end{array}$ & $\begin{array}{l}0.107 \pm 0.017 \\
(0.085-0.125)\end{array}$ \\
\hline Moisture content (\%) & $\begin{array}{l}4.66 \pm 1.04 \\
(4.1-6.5)\end{array}$ & $\begin{array}{l}7.29 \pm 1.54 \\
(6.1-10.4)\end{array}$ \\
\hline $\operatorname{SOC}(\%)^{\mathrm{b}}$ & $\begin{array}{l}4.27 \pm 0.91 \\
(3.23-5.41)\end{array}$ & $\begin{array}{l}2.02 \pm 0.20 \\
(1.75-2.15)\end{array}$ \\
\hline Av. $\mathrm{N}\left(\mathrm{mg} \mathrm{kg}^{-1}\right)$ & $\begin{array}{l}94.50 \pm 11.47 \\
(84-110)\end{array}$ & $\begin{array}{l}126.77 \pm 11.02 \\
(108.2-144.2)\end{array}$ \\
\hline $\mathrm{Av}-\mathrm{P}\left(\mathrm{mg} \mathrm{kg}^{-1}\right)$ & $\begin{array}{l}2.45 \pm 0.69 \\
(1.82-3.32)\end{array}$ & $\begin{array}{l}6.85 \pm 1.41 \\
(4.5-8.84)\end{array}$ \\
\hline
\end{tabular}

${ }^{\text {a }}$ Avg value \pm SD (Min - Max)

b By Walkley-Black method (rapid dichromate digestion)

substrate and nature of the geological material of the overburden dump (the amount of acid-producing or acidneutralizing material) (Mukhopadhyay and Maiti 2011). In the present study $\mathrm{pH}$ and electrical conductivity was found within the range and anticipate no detrimental effects on plant growth.

Variations in SOC may be mainly due to nature of mine soil, as well as decomposition of leaf litter of different tree species and humus to a large extent. The average SOC was found higher $(4.27 \%)$, due to accumulation of old, new and coal carbon fraction or mixing of recent carbon with coal carbon (Ussiri and Lal 2008). It has been reported that coalmine soil contains both recent (new) plant derived carbon fractions added through biological processes, detritus matter; and ancient (old) carbon fractions added by fossilized plant matter (humus), coal and inorganic carbonates (Maharaj et al. 2007). Plant available nitrogen was $94 \mathrm{mg} \mathrm{kg}^{-1}$, which is lower than reference forest site, due to younger age of RMS. In the RMS, plant available P was $2.5 \mathrm{mg} \mathrm{kg}^{-1}$, which also much lower than reference forest site. SOC, $\mathrm{N}$ and $\mathrm{P}$ have been reported as growth limiting factors on mined sites, but usually within the first 10-year after disturbance (Andrews et al. 2002). Increase in concentration of available $\mathrm{N}$ with increase in age of plantation has been observed by several researchers (Ahirwal and
Maiti 2016; Mukhopadhyay and Maiti 2014; Maiti 2006, 2007). Low available $\mathrm{N}$ stock in the younger RMS suggests that $\mathrm{N}$ is limiting initially after reclamation when very little organic matter is present. Nitrogen accumulation is controlled by organic carbon input and $\mathrm{N}$ fixation, while phosphorus content is determined by the organic matter, $\mathrm{pH}$ of the soil substrate and weathering process (Andrews et al. 2002). Several chronosequence studies (Akala and Lal 2000; Maharaj et al. 2007; Shrestha and Lal 2010; Mukhopadhyay et al. 2013, 2014) have reported accumulation of $\mathrm{C}$ and $\mathrm{N}$ pools over time in RMS.

\subsection{Tree biomass $\mathrm{C}$ stock and $\mathrm{CO}_{2}$ sequestration}

Tree species with $\mathrm{DBH}>3 \mathrm{~cm}$ found within the quadrat were classified according to DBH classes as applicable. A. lebbeck, the most dominant species was classified into 5 DBH classes ranging from 3 to $5 \mathrm{~cm}, 5$ to $7 \mathrm{~cm}, 7$ to $9 \mathrm{~cm}$, 9 to $11 \mathrm{~cm}$ and 11 to $13 \mathrm{~cm}$, with a total of 1433 nos of trees $\mathrm{ha}^{-1}$ and average $\mathrm{DBH}$ ranging from 4.08 to $12.42 \mathrm{~cm}$ (Table 3). Likewise, average DBH for other tree species were calculated. Out of 7 species, A. lebbeck contributed maximum AGB (13.04 $\mathrm{Mg} \mathrm{ha}^{-1}$ ) followed by D. sissoo (5.96 $\mathrm{Mg} \mathrm{ha}^{-1}$ ). The root biomass contributed by A. lebbeck was also highest $\left(2.61 \mathrm{Mg} \mathrm{ha}^{-1}\right)$ than other tree 
Table 3 Estimation of above ground biomass (AGB) and root biomass (RB) based on DBH (diameter at breast height) class for individual tree species in reclaimed site

\begin{tabular}{|c|c|c|c|c|c|c|}
\hline Tree species name & $\begin{array}{l}\text { DBH range } \\
(\mathrm{cm})\end{array}$ & $\begin{array}{l}\text { Avg DBH } \\
(\mathrm{cm})\end{array}$ & $\begin{array}{l}\text { No of trees } \\
\mathrm{ha}^{-1}\end{array}$ & $\begin{array}{l}\text { AGB per tree } \\
(\mathrm{kg})\end{array}$ & $\begin{array}{l}\text { AGB of all trees } \\
\left(\mathrm{Mg} \mathrm{ha}^{-1}\right)\end{array}$ & $\begin{array}{l}\text { Root biomass (RB) } \\
\left(\mathrm{Mg} \mathrm{ha}^{-1}\right)^{\mathrm{a}}\end{array}$ \\
\hline \multirow[t]{6}{*}{ Alzebia. lebbeck } & $3-5$ & 4.08 & 600 & $3.54^{\mathrm{b}}$ & $2.12^{\mathrm{c}}$ & $0.42^{\mathrm{d}}$ \\
\hline & $5-7$ & 5.88 & 533 & 8.27 & 4.41 & 0.88 \\
\hline & $7-9$ & 7.91 & 200 & 16.47 & 3.29 & 0.66 \\
\hline & $9-11$ & 9.43 & 67 & 24.76 & 1.65 & 0.33 \\
\hline & $11-13$ & 12.42 & 33 & 46.94 & 1.56 & 0.31 \\
\hline & & Total & 1433 & & 13.04 & 2.61 \\
\hline \multirow[t]{2}{*}{ Alstonia scholaris } & $3-5$ & 3.18 & 33 & 2.00 & 0.07 & 0.01 \\
\hline & & Total & 33 & & 0.07 & 0.013 \\
\hline \multirow[t]{4}{*}{ Dalbergia sissoo } & $3-5$ & 4.31 & 300 & 4.02 & 1.21 & 0.24 \\
\hline & $5-7$ & 5.80 & 467 & 8.02 & 3.74 & 0.75 \\
\hline & $7-9$ & 7.64 & 67 & 15.22 & 1.01 & 0.20 \\
\hline & & Total & 833 & & 5.96 & 1.19 \\
\hline \multirow[t]{2}{*}{ Mitragyna parviflora } & $3-5$ & 3.82 & 33 & 3.05 & 0.10 & 0.02 \\
\hline & & Total & 33 & & 0.10 & 0.02 \\
\hline \multirow[t]{2}{*}{ Phyllanthus emblica } & $3-5$ & 3.40 & 100 & 2.32 & 0.23 & 0.05 \\
\hline & & Total & 100 & & 0.23 & 0.05 \\
\hline \multirow[t]{2}{*}{ Syzygium cumini } & $3-5$ & 4.78 & 33 & 5.11 & 0.17 & 0.03 \\
\hline & & Total & 33 & & 0.17 & 0.03 \\
\hline \multirow[t]{2}{*}{ Ziziphus oenoplia } & $3-5$ & 3.82 & 33 & 3.05 & 0.10 & 0.02 \\
\hline & & Total & 33 & & 0.10 & 0.02 \\
\hline
\end{tabular}

a Root biomass (MacDicken 1997) $=$ AGB $\left(\mathrm{Mg} \mathrm{ha}^{-1}\right) \times 0.2$

b $\mathrm{AGB}(\mathrm{kg})=\exp [-1.996+2.32 \times \ln \mathrm{DBH}(\mathrm{cm})] ;=\exp [-1.996+2.32 \times \ln (4.08)]=3.54 \mathrm{~kg}$

c $3.54 \mathrm{~kg}$ x $600\left(\right.$ no of trees ha $\left.{ }^{-1}\right) \times 10^{-3}=2.12\left(\mathrm{Mg} \mathrm{ha}^{-1}\right)$

d $2.12\left(\mathrm{Mg} \mathrm{ha}^{-1}\right) \times 0.2=0.42\left(\mathrm{Mg} \mathrm{ha}^{-1}\right)$

species. It is noticed that AGB $\left(\mathrm{kg}\right.$ tree $\left.{ }^{-1}\right)$ increases exponentially at the higher DBH. Similar exponential relationship was noticed between biomass and DBH of tropical trees (Brown 1997).

Total tree biomass was estimated $23.6 \mathrm{Mg} \mathrm{ha}^{-1}$ (AGB 19.67 $\mathrm{Mg} \mathrm{ha}^{-1}+\mathrm{RB} 3.93 \mathrm{Mg} \mathrm{ha}^{-1}$ ) (Table 4) and the biomass of bamboo clumps was estimated as $2.54 \mathrm{Mg} \mathrm{ha}^{-1}$. Singh and Singh (1999) reported bamboo plantation developed on reclaimed mine spoil (Singrauli, India) accumulated substantial amount of biomass (46 $\mathrm{Mg} \mathrm{ha}^{-1}$ for 3 year plantation and $74.7 \mathrm{Mg} \mathrm{ha}^{-1}$ for 5 year plantation). Several other studies in natural ecosystem of bamboo forests and plantations in India recorded 0.8 to $24 \mathrm{Mg} \mathrm{ha}^{-1}$ aboveground biomass (Rao and Ramakrishnan 1989; Tripathi and Singh 1996). In the present study, total biomass (tree and bamboo) was estimated 25.97 $\mathrm{Mg} \mathrm{ha}^{-1}$. Studies by Singh and Singh (1991) reported higher aboveground biomass in the native dry tropical deciduous forest, in the range between 42 and $78 \mathrm{Mg} \mathrm{ha}^{-1}$. Lodhiyal et al. (2002) estimated the AGB of Tarai Shisham forest, India (5-15 years age) in the range of
41-103 $\mathrm{Mg} \mathrm{ha}^{-1}$ and total biomass in the range of 59-136 $\mathrm{Mg} \mathrm{ha}^{-1}$.

Biomass $\mathrm{C}$ stock in reclaimed mine sites depends on tree species, climatic conditions and nature of substrate. A comparative $\mathrm{C}$ stock data under different climatic conditions, age of vegetation and forest type is presented in Table 5. In the present study, total biomass $\mathrm{C}$ stock was estimated as $13 \mathrm{MgC} \mathrm{ha}^{-1}$ (equivalent to $\mathrm{CO}_{2}$ sequestered of $47.96 \mathrm{Mg} \mathrm{CO}_{2} \mathrm{ha}^{-1}$ ), which is much lower than reference forest site. In Indian conditions (19 years old RMS of Singrauli, India), Tripathi et al. (2014) reported higher C stock $\left(41.73 \mathrm{Mg} \mathrm{C} \mathrm{ha}^{-1}\right)$ with an accumulation rate of $2.20 \mathrm{Mg} \mathrm{C}^{-1}$ year $^{-1}$. Average $\mathrm{C}$ accumulation rate in aboveground biomass for reclaimed pine and hardwood forests ranged from $1.4 \mathrm{Mg} \mathrm{C}^{-1}$ year $^{-1}$ in Indiana to 3.3 $\mathrm{Mg} \mathrm{C} \mathrm{ha}^{-1}$ year $^{-1}$ in West Virginia (Amichev et al. 2008). Terakunpisut et al. (2007) compared the $C$ stock of the aboveground biomass in different forest ecosystems of Thong Pha Phum National Forest, Thailand based on $\mathrm{DBH} \geq 4.5 \mathrm{~cm}$ using allometric equation and reported that tropical rain forest had higher $\mathrm{C}$ stock than dry evergreen 
Table 4 Distribution of carbon stock in total above ground biomass (AGB), root biomass (RB) of trees and bamboo in reclaimed area

\begin{tabular}{lrrll}
\hline Tree species name & $\begin{array}{l}\text { Nos } \\
\mathrm{ha}^{-1}\end{array}$ & AGB of tree species $\left(\mathrm{Mg} \mathrm{ha}^{-1}\right)$ & $\mathrm{RB}$ of tree species $\left(\mathrm{Mg} \mathrm{ha}^{-1}\right)$ & ${\text { Biomass C-stock }\left(\mathrm{Mg} \mathrm{C}^{-1}\right)}$ \\
\hline Albizia spp & 1433 & 13.04 & 2.61 & 7.82 \\
Dalbergia sissoo & 833 & 5.96 & 1.19 & 3.58 \\
Other tree species $^{\mathrm{a}}$ & 234 & 0.67 & 0.13 & 0.40 \\
$\begin{array}{l}\text { B. } \text { arundinecea }^{\mathrm{b}} \\
\quad \text { (Clumps) }\end{array}$ & 2033 & 2.36 & 0.18 & 1.27 \\
Total & & 22.03 & 4.11 & 13.07 \\
\hline
\end{tabular}

${ }^{a}$ Alstonia scholaris, Mitragyna parviflora, Phyllanthus emblica, Syzygium cumini and Ziziphus oenoplia

b Singh and Singh (1999) studied the biomass C of bamboo in the reclaimed mine sites of Singrauli, India, and reported that after 4 years, nos of clumps were 22475, which contributes above ground biomass of $26.1 \mathrm{Mg} \mathrm{ha}^{-1}$ (or $13.05 \mathrm{Mg} \mathrm{C} \mathrm{ha}^{-1}$ ) and root biomass contributes $7.7 \%$ of total biomass. So, in the present study, above ground bamboo biomass of 2033 nos clumps ha ${ }^{-1}$,is calculated as $2.36 \mathrm{Mg}^{-1}$. $\mathrm{CO}_{2}$ sequestered $=13.07 \mathrm{t} \mathrm{ha}^{-1} \times 3.67$ (factor to convert $\mathrm{C}$ to $\mathrm{CO}_{2}$ ) $=47.96 \mathrm{MgCO}_{2}$ ha $^{-1}$. Therefore, rate of $\mathrm{CO}_{2}$ sequestration $=\left[47.96 \mathrm{Mg} \mathrm{ha}^{-1} /\right.$ 4 years) $=12 \mathrm{Mg} \mathrm{CO}_{2} \mathrm{ha}^{-1}$ year $^{-1}$

and mixed deciduous forest in order of $137.7 \pm 48$, $70.3 \pm 7.4$ and $48 \pm 16.7 \mathrm{Mg} \mathrm{C}^{-1}$, respectively.

\subsection{C stock in understorey vegetation and litter and $\mathrm{CO}_{2}$ sequestration}

Litter accumulation underneath of different trees and bamboo plantation were estimated in this study, which includes dry leaves, grasses, herbs and shrubs. In the present study average litter accumulation was $2.45 \mathrm{Mg} \mathrm{ha}^{-1}$, and total $\mathrm{C}$ stock estimated as $0.98 \mathrm{Mg} \mathrm{C}^{-1}$ (0.3-1.86 $\mathrm{Mg} \mathrm{C} \mathrm{ha}^{-1)}$, which is lower than reference forest site (Table 6). Dutta and Agarwal (2003) estimated overall litterfall rate in the range of $1.2-3.6 \mathrm{Mg} \mathrm{ha}^{-1}$ year $^{-1}$ in reclaimed coalmine site (Singraulli, India), whereas range 1-5.9 $\mathrm{Mg} \mathrm{ha}{ }^{-1}$ year $^{-1}$ was reported in established bamboo ecosystem of the same site (Tripathi and Singh 1996; Singh and Singh1999). Litterfall rate in Indian shisham forest (5-15 yrs age) was estimated in similar range of 2.2-5.1 Mg ha ${ }^{-1}$ year $^{-1}$ (Lodhiyal et al. 2002).

In the present study, carbon stored in the understorey vegetation and litter components was $0.98 \mathrm{Mg} \mathrm{C} \mathrm{ha}^{-1}$, which is lower than other reported values. (Karu et al. 2009; Pragasan and Parthasarathy 2005). C stock in litter component of reclaimed minesoil of Midwestern and Appalachian coalfields (USA) comprised of pine, hardwood and mixed stand was estimated 21.2, 14 and $6 \mathrm{Mg} \mathrm{ha}^{-1}$ respectively (Amichev et al. 2008). Other studies by Shrestha and Lal (2010) also estimated higher C stock than the present study in litter component of reclaimed minesoil of Ohio (USA) in forest ecosystem (3.96 $\mathrm{Mg} \mathrm{Cha}^{-1}$ ). In Indian mining conditions (revegetated minespoils of 19 years age, Singrauli, India) C accumulation by litter component was estimated $2.80 \mathrm{Mg} \mathrm{C}$ ha $^{-1}$ @ $0.15 \mathrm{Mg} \mathrm{C} \mathrm{ha}^{-1}$ year $^{-1}$ (Tripathi et al. 2014), which is higher than the present study. Studies reported that, with increase age of vegetation $\mathrm{C}$ stock in the understorey vegetation and litter fall also increases (Amichev et al. 2008; Singh et al. 2011).

\section{4 $\mathrm{C}$ stock in reclaimed mine soil and $\mathrm{CO}_{2}$ sequestration}

C-stock in reclaimed mine soil (RMS) was estimated 16.33 $\mathrm{MgC} \mathrm{ha}^{-1}$ and $\mathrm{CO}_{2}$ sequestered was $59.93 \mathrm{Mg} \mathrm{CO}_{2}$ $\mathrm{ha}^{-1}$, which is lower than reference forest site (Table 7). In Indian reclaimed coal mine sites (Jayant project, Singrauli) accumulation of higher $\mathrm{C}$-stock $\left(22.9 \mathrm{Mg} \mathrm{C} \mathrm{ha}^{-1}\right)$ was reported with an average accumulation rate of 1.20 Mg C ha ${ }^{-1}$ year $^{-1}$ (Tripathi et al. 2014). C stocks of reclaimed forest and grassland coal mine soils $(0-30 \mathrm{~cm})$ of Ohio, USA were reported in higher range of $37-45 \mathrm{Mg} \mathrm{C}$ $\mathrm{ha}^{-1}$ and $47-79 \mathrm{Mg} \mathrm{C} \mathrm{ha}^{-1}$ over 21 and 25 year periods respectively (Akala and Lal 2000, 2001). Rate of accumulation of $\mathrm{C}$ stock was observed 0.1 to $3.1 \mathrm{Mg} \mathrm{C}^{-1}$ year $^{-1}$ and $0.7-4 \mathrm{Mg} \mathrm{C} \mathrm{ha}^{-1}$ year $^{-1}$ in grass and forest RMS ecosystem respectively (Shrestha and Lal 2006; Akala and Lal 2001). Post and Kwon (2000) also reported a higher average $\mathrm{C}$ accumulation of $0.34 \mathrm{Mg} \mathrm{C}^{-1}$ year $^{-1}$ (at the top $30 \mathrm{~cm}$ soil in tropical to temperate forest) than permanent grasslands $\left(0.74 \mathrm{Mg} \mathrm{ha}^{-1}\right.$ year $^{-1}$ tropical dry lands to cool temperate ecoregion) which is lower than the RMS.

\subsection{Total soil carbon fractionation of RMS}

The total soil carbon content is considered as a key component of minesoil quality and its storage in reclaimed soil is recognized promising measure for mitigating global climate change through carbon sequestration (Lal 2004, 2005). Distribution of Total carbon (\%), Inorganic 
Table 5 C-stock in Total biomass, Above ground biomass (AGB) and accumulation rate under forest and reclaimed coal mine spoils in India and outside countries

\begin{tabular}{|c|c|c|c|c|c|}
\hline Forest type/vegetation and location & Age (year) & $\begin{array}{l}\text { Total biomass } \mathrm{C} \\
\left(\mathrm{Mg} \mathrm{C} \mathrm{ha}^{-1}\right)\end{array}$ & $\begin{array}{l}\text { AGB C stock } \\
\left(\mathrm{Mg} \mathrm{C} \mathrm{ha}^{-1}\right)\end{array}$ & $\begin{array}{l}\text { Total biomass } \mathrm{C} \text { accumulation } \\
\text { rate }\left(\mathrm{Mg} \mathrm{C} \mathrm{ha}^{-1} \mathrm{yr}^{-1}\right)\end{array}$ & Reference \\
\hline \multirow{3}{*}{$\begin{array}{l}\text { Reclaimed minesoil, Northern } \\
\text { Europe (Pinus sylvestris) }\end{array}$} & 14 & 6.76 & 5.86 & 0.48 & \multirow[t]{3}{*}{ Karu et al. (2009) } \\
\hline & 21 & 28.93 & 25.65 & 1.37 & \\
\hline & 36 & 101.6 & 90.01 & 2.82 & \\
\hline \multirow{3}{*}{$\begin{array}{l}\text { Reforested post-mining sites, Poland } \\
\quad \text { (Pinus sylvestris) }\end{array}$} & 17 & 24.41 & 22.13 & 1.43 & \multirow{3}{*}{$\begin{array}{l}\text { Pietrzykowski and } \\
\text { Daniels (2014) }\end{array}$} \\
\hline & 30 & 54.74 & 48.17 & 1.82 & \\
\hline & $\begin{array}{l}\text { Con } \\
(30 \mathrm{yr})\end{array}$ & 71.10 & 64.50 & 2.37 & \\
\hline \multirow{5}{*}{$\begin{array}{l}\text { Reforested coal mine sites of } \\
\text { Appalachian Coal Basin, USA }\end{array}$} & 5 & 2.49 & 0.27 & 0.50 & \multirow[t]{5}{*}{ Avera et al. (2015) } \\
\hline & 11 & 55.43 & 53.80 & 5.04 & \\
\hline & 21 & 54.10 & 48.86 & 2.58 & \\
\hline & 30 & 66.91 & 64.27 & 2.23 & \\
\hline & Unmined & 136.09 & 125.71 & - & \\
\hline \multirow[t]{3}{*}{ D. sissoo forests, Tarai forest, India } & 5 & 29.3 & 20.9 & 5.86 & \multirow{3}{*}{$\begin{array}{l}\text { Lodhiyal et al. } \\
\text { (2002) }\end{array}$} \\
\hline & 10 & 53 & 39.3 & 5.30 & \\
\hline & 15 & 68 & 50.65 & 4.53 & \\
\hline \multirow{3}{*}{$\begin{array}{l}\text { D. sissoo forests, Bhabar forest, } \\
\text { India }\end{array}$} & 5 & 17.55 & - & 3.51 & \multirow{3}{*}{$\begin{array}{l}\text { Lodhiyal and. } \\
\text { Lodhiyal (2003) }\end{array}$} \\
\hline & 10 & 30.15 & - & 6.03 & \\
\hline & 15 & 44.75 & - & 2.98 & \\
\hline Mixed plantation, Terai, India ${ }^{a}$ & 5 & 5.88 & 4.385 & 1.176 & Singh et al. (2011) \\
\hline D. sissoo, & & 0.325 & 0.285 & 0.065 & \\
\hline A. lebbeck & & 1.51 & 1.30 & 0.302 & \\
\hline \multicolumn{6}{|l|}{ A. catechu } \\
\hline D. sissoo, Tarai, India & 10 & 43.39 & 35.77 & 2.73 & $\begin{array}{l}\text { Kanime et al. } \\
\text { (2013) }\end{array}$ \\
\hline \multirow{5}{*}{$\begin{array}{l}\text { Tropical moist deciduous forests, } \\
\text { Techtona grandis Tarai, India }\end{array}$} & 5 & 15.8 & 13.9 & $3.16 \#$ & \multirow[t]{5}{*}{ Jha (2015) } \\
\hline & 11 & 35.4 & 31.2 & 3.21 & \\
\hline & 18 & 39.0 & 34.2 & 2.17 & \\
\hline & 24 & 61.5 & 54.3 & 2.65 & \\
\hline & 30 & 73.2 & 63.8 & 2.44 & \\
\hline \multirow{2}{*}{$\begin{array}{l}\text { Reclaimed coal mine spoil, } \\
\text { Singrauli, India B. arundinacea }\end{array}$} & 3 & 23.45 & 21.65 & 7.81 & \multirow{2}{*}{$\begin{array}{l}\text { Singh and Singh } \\
\text { (1999) }\end{array}$} \\
\hline & 5 & 37.35 & 34.7 & 7.47 & \\
\hline \multirow{2}{*}{$\begin{array}{l}\text { Reclaimed coal mine spoil, } \\
\text { Singrauli, India }\end{array}$} & 2 & 1.74 & 1.52 & 0.87 & \multirow{6}{*}{$\begin{array}{l}\text { Tripathi et al. } \\
\text { (2016) }\end{array}$} \\
\hline & 4 & 5.45 & 4.75 & 1.36 & \\
\hline \multirow[t]{4}{*}{ (Mixed plantation) } & 10 & 15.64 & 13.68 & 1.56 & \\
\hline & 14 & 25.96 & 23.04 & 1.85 & \\
\hline & 16 & 31.61 & 27.89 & 1.97 & \\
\hline & 19 & 44.52 & 39.25 & 2.34 & \\
\hline \multirow{2}{*}{$\begin{array}{l}\text { Reclaimed coal mine spoil, } \\
\quad \text { Singrauli, India }\end{array}$} & 3 & 10.95 & 7.8 & 3.65 & \multirow[t]{4}{*}{ Singh et al. (2011) } \\
\hline & 6 & 33.9 & 25.55 & 5.65 & \\
\hline A. lebbek & 3 & 6.55 & 3.2 & 2.18 & \\
\hline A. procera & 6 & 20.1 & 13.65 & 3.35 & \\
\hline \multirow{2}{*}{$\begin{array}{l}\text { Reclaimed coalmine, A. lebbeck, D. } \\
\text { sissoo, } \\
\text { B. arundinacea }\end{array}$} & 4 & 13 & 11.01 & 3.25 & \multirow[t]{2}{*}{ Present study } \\
\hline & $\begin{array}{l}\text { Reference } \\
\text { forest }^{\mathrm{b}}\end{array}$ & 66.1 & 52.88 & - & \\
\hline
\end{tabular}


Table 6 Carbon stock of understory vegetation and litter in 4 years old reclaimed dump

\begin{tabular}{|c|c|c|c|c|}
\hline Forest type/vegetation, location & Components & $\begin{array}{l}\text { Age of reclamation } \\
\text { (years) }\end{array}$ & $\begin{array}{l}\text { C- stock (Mg C } \\
\left.\text { ha }^{-1}\right)^{\mathrm{a}}\end{array}$ & Reference \\
\hline Reclaimed minesoil, Appalachian, USA & $\begin{array}{l}\text { Pine stands } \\
\text { Hardwood stands } \\
\text { Mixed stands }\end{array}$ & - & $\begin{array}{l}21.2 \\
13.9 \\
6.1\end{array}$ & Amichev et al. (2008) \\
\hline $\begin{array}{l}\text { Reclaimed minesoil, Northern Europe (Pinus } \\
\text { sylvestris) }\end{array}$ & Herb + Shrub & $\begin{array}{l}14 \\
21 \\
36\end{array}$ & $\begin{array}{l}6.76 \\
0.62 \\
7.8\end{array}$ & Karu et al. (2009) \\
\hline Reclaimed minesoil of Ohio, USA & Forest & 25 & 3.96 & Shrestha and Lal (2010) \\
\hline $\begin{array}{l}\text { Tropical dry evergreen forests, Coromandel } \\
\text { coast, south India }\end{array}$ & $\begin{array}{l}\text { Total fine litter } \\
\text { Standing crop }\end{array}$ & & $\begin{array}{l}5.3-5.4 \\
1.64-1.94\end{array}$ & $\begin{array}{l}\text { Pragasan and } \\
\quad \text { Parthasarathy (2005) }\end{array}$ \\
\hline Terai Forest, India & $\begin{array}{l}\text { Understorey } \\
\text { Floor litter }\end{array}$ & 5 & $\begin{array}{l}1.62 \\
0.608\end{array}$ & Singh et al. (2011) \\
\hline Revegetated mine spoils, India & & 19 & $2.80(0.15)^{\mathrm{b}}$ & Tripathi et al. (2014) \\
\hline Temperate forests, Kashmir, India & $\begin{array}{l}\text { Understorey } \\
\text { Detritus }\end{array}$ & Natural forest- & $\begin{array}{l}0.08-1.18 \\
2.01-8.06\end{array}$ & $\begin{array}{l}\text { Dar and Sundarapandian } \\
\text { (2015) }\end{array}$ \\
\hline Reclaimed coalmine, site, Jharia coalfields & $\begin{array}{l}\text { Understory vegetation } \\
\text { and litter } \\
\text { Reference forest site }\end{array}$ & $\begin{array}{l}4 \\
-\end{array}$ & $\begin{array}{l}0.98 \\
(0.288-1.856) \\
1.65 \\
(0.842-2.103)\end{array}$ & Present study \\
\hline
\end{tabular}

Undestorey vegetation includes herbs, shrubs and grasses

a Total biomass is multiplied by 0.4 to calculate C-stock

b Values within brackets are $\mathrm{C}$ sequestration rate of understorey vegetation and litter

carbon (\%), Coal carbon (\%) and Biogenic carbon (\%) of RMS samples collected under the canopy of different vegetation cover is shown in (Fig. 11). Total soil carbon (TSC) was found in the range of $1.72 \%-2.31 \%$ and the average value was $2.01 \%$. Carbon fractionation is important since intermixing of biogenic $\mathrm{C}$ with coal $\mathrm{C}$ leads to overestimation of $\mathrm{C}$ sequestration values (Ussiri and Lal 2005; Ussiri et al. 2014). In the present study, inorganic C was estimated as $0.17 \%$, which is $8 \%$ of TSC. Stahl et al. (2009) reported IC concentration from 1.82 to $8.47 \mathrm{~g} \mathrm{C} \mathrm{kg}^{-1}$ in RMS (17\%-60\% of TSC) of Wyoming (USA). Ussiri and Lal (2008) reported coal C contributes $47.4 \%$ of TSC $(0-10 \mathrm{~cm})$ in the RMS of Ohio. The quantity and quality of biogenic $\mathrm{C}$ have strong influences on other essential soil characteristics and is a major determinant of soil productivity and long-term stability of the reclaimed minesoil (Ussiri et al. 2014). Biogenic $\mathrm{C}$ was estimated in the present study in the range of $0.84 \%-1.08 \%$, whereas coal C was estimated $0.63 \%-1.03 \%$.

\subsection{Coal $\mathrm{C}$ distribution in reclaimed minesoils}

Depending on mining and reclamation techniques, the amount of coal $\mathrm{C}$ can be substantial (Table 8). In the present study, coal $\mathrm{C}$ contributed $43 \%$ of total organic carbon (TOC) in RMS. In Indian conditions, average contribution of coal $\mathrm{C}$ to TOC in RMS ranged between $24 \%$ and $68 \%$ (Das and Maiti 2016). Coal contamination contributed to the irregular depth distribution of SOC in RMS (Thurman and Sencindiver 1986). In Lusatia mining district (Germany), lignite-C accounted for $25 \%$ to $99 \%$ of the total SOC in rehabilitated and reforested RMS (Rumpel et al. 1998, 2000). Coal C accounted for up to $80 \%$ of the OC in the A- horizon of cultivated Mollisol contaminated by brown coal emissions from a briquette factory (Schmidt et al. 1996). Chabbi et al. (2006) reported lignite C contribution of $20 \%-80 \%$ of total SOC in RMS and sediment of Lusatia (Germany). Generally, the concentration of coal $\mathrm{C}$ increases with increase in soil depth, and nearly $100 \%$ of OC in the C- horizon (mine spoil) can be of geogenic origin (Ussiri et al. 2014).

Age since reclamation had little effect on the relative abundance of Coal C in RMS probably due to its biochemical recalcitrance. For example, Rumpel et al. (2003) showed that lignite accounted for $80 \%-93 \%$ of the total C in the top $0-5 \mathrm{~cm}$ mineral horizon of the age-chronosequence series of minesoils ranging from 11 to 32 year old at Lusatian mining district in Germany. Rumpel et al. (1998) observed that after 36 year of restoration, more than half of the OC in 0-5 cm soil layer under red oak (Querus 
Table 7 Soil carbon stock and rate of accumulation in afforested reclaimed coal mine soils and natural forest in India and abroad

\begin{tabular}{|c|c|c|c|c|c|c|}
\hline Land use & $\begin{array}{l}\text { Vegetation/land- } \\
\text { use system }\end{array}$ & $\begin{array}{l}\text { Age } \\
\text { (year) }\end{array}$ & $\begin{array}{l}\text { Soil depth } \\
(\mathrm{cm})\end{array}$ & $\begin{array}{l}\text { C stock }(\mathrm{MgC} \\
\left.\mathrm{ha}^{-1}\right)\end{array}$ & $\begin{array}{l}\text { Rate of C accumulation } \\
\left(\mathrm{MgC} \mathrm{ha}^{-1} \text { year }^{-1}\right.\end{array}$ & Reference \\
\hline \multirow{2}{*}{$\begin{array}{l}\text { Reclaimed minesoil Ohio, } \\
\text { USA }\end{array}$} & Pasture & 25 & $0-30$ & 36.7 & 1.468 & \multirow{2}{*}{$\begin{array}{l}\text { Akala and Lal } \\
\quad(2000)\end{array}$} \\
\hline & Forest & 25 & $0-30$ & 37.1 & 1.484 & \\
\hline \multirow{8}{*}{$\begin{array}{l}\text { Reclaimed minesoil, } \\
\text { Ohio, USA }\end{array}$} & \multirow{2}{*}{$\begin{array}{l}\text { Pasture (with top } \\
\text { soil) }\end{array}$} & \multirow[t]{2}{*}{$0-25$} & $0-15$ & $9.2-55.4$ & $3.1-0.5$ & \multirow{8}{*}{$\begin{array}{l}\text { Akala and Lal } \\
\text { (2001) }\end{array}$} \\
\hline & & & $15-30$ & $7.8-37.8$ & $1.9-0.4$ & \\
\hline & \multirow{2}{*}{$\begin{array}{l}\text { Forest (with top } \\
\text { soil) }\end{array}$} & \multirow[t]{2}{*}{$0-21$} & $0-15$ & $14-48.4$ & $2.3-07$ & \\
\hline & & & $15-30$ & $8.4-14.5$ & $0.4-0.3$ & \\
\hline & \multirow{2}{*}{$\begin{array}{l}\text { Pasture (No top } \\
\text { soil) }\end{array}$} & \multirow[t]{2}{*}{$30-40$} & $0-15$ & $60-67$ & \multirow[t]{2}{*}{-} & \\
\hline & & & $15-30$ & $34-40$ & & \\
\hline & \multirow{2}{*}{$\begin{array}{l}\text { Forest (No top } \\
\quad \text { soil) }\end{array}$} & \multirow[t]{2}{*}{$30-50$} & $0-15$ & $50-70$ & \multirow[t]{2}{*}{-} & \\
\hline & & & $15-30$ & $27-47$ & & \\
\hline $\begin{array}{l}\text { Reclaimed mine soil, } \\
\text { Central Appalachian, } \\
\text { USA }\end{array}$ & $\begin{array}{l}\text { Mixed hardwood } \\
\text { forest }\end{array}$ & 40 & $0-10$ & - & 4.0 & Burger (2004) \\
\hline \multirow{2}{*}{$\begin{array}{l}\text { Reclaimed minesoil, Ohio } \\
\text { USA }\end{array}$} & Hardwood forest & \multirow[t]{2}{*}{-} & \multirow[t]{2}{*}{-} & 81 & \multirow[t]{2}{*}{-} & \multirow[t]{2}{*}{ Jacinthe et al. (2004) } \\
\hline & Grassland & & & 71 & & \\
\hline \multirow{3}{*}{$\begin{array}{l}\text { Reclaimed minesoil } \\
\text { Appalachian, USA }\end{array}$} & Pine stands & \multirow[t]{3}{*}{-} & \multirow[t]{3}{*}{-} & 11 & \multirow[t]{3}{*}{-} & \multirow{3}{*}{$\begin{array}{l}\text { Amichev et al. } \\
\text { (2008) }\end{array}$} \\
\hline & Hardwood stands & & & 13 & & \\
\hline & Mixed stands & & & 17.7 & & \\
\hline \multirow{3}{*}{$\begin{array}{l}\text { Reclaimed minesoil, } \\
\text { northern Europe } \\
\text { (Estonia) }\end{array}$} & \multirow{3}{*}{$\begin{array}{l}\text { Forest (Scots } \\
\text { pine) }\end{array}$} & 14 & \multirow{3}{*}{$\begin{array}{l}\text { O- and A- } \\
\text { horizon } \\
(0.2 .8)\end{array}$} & $0.1 \& 0.2$ & $0.33 \& 0.51$ & Karu et al. (2009) \\
\hline & & 21 & & $4.6 \& 0.4$ & & \\
\hline & & 36 & & $12.3 \& 19.0$ & & \\
\hline Reclaimed mine soils, & Scots pine (Pinus & $12-30$ & - & $0.73^{\mathrm{a}}$ & 1.45 & Pietrzykowski and \\
\hline Poland & sylvestris) & & & $2.17^{\mathrm{b}}$ & & Krzaklewski \\
\hline & & & & $5.26^{\mathrm{c}}$ & & \\
\hline Reclaimed minesoil of & Forest & 25 & $0-15$ & 38 & 1.52 & Shrestha and Lal \\
\hline Ohio, USA & Pasture & 25 & $0-15$ & 35 & 1.4 & (2010) \\
\hline Reforested coal mine & Mixed plantation $^{1}$ & 5 & - & 7.02 & - & Avera et al. (2015) \\
\hline sites, Appalachian, & & 11 & & 13.52 & & \\
\hline & & 21 & & 21.35 & & \\
\hline & & 30 & & 16.62 & & \\
\hline & & Unmined & & 42.85 & & \\
\hline $\begin{array}{l}\text { Central Himalayan Tarai, } \\
\text { India }\end{array}$ & $\begin{array}{l}\text { D. sissoo } \\
\text { monoculture } \\
\text { plantation }\end{array}$ & 10 & $0-30$ & 36.3 & - & Kanime et al. (2013) \\
\hline $\begin{array}{l}\text { Temperate forests } \\
\text { Kashmir, India }\end{array}$ & $\begin{array}{l}\text { Broad leaved } \\
\text { species and } \\
\text { conifers }\end{array}$ & $\begin{array}{l}\text { Natural } \\
\text { forest }\end{array}$ & $0-30$ & $39.1-91.4$ & - & $\begin{array}{l}\text { Dar and } \\
\text { Sundarapandian } \\
(2015)\end{array}$ \\
\hline $\begin{array}{l}\text { Revegetated coal mines, } \\
\text { Singrauli, India }\end{array}$ & Afforest site & 19 & $0-30$ & 22.9 & 1.20 & Tripathi et al. (2014) \\
\hline Reclaimed coalmine, site, & Afforest site & 4 & $0-15$ & $16.33 \pm 1.04$ & 4.08 & Present study \\
\hline Jharia coalfields & Forest (reference) & - & $0-15$ & (14.96-17.25) & & \\
\hline & & & & $35.5 \pm 5.8$ & & \\
\hline & & & & $(30.4-42.5)$ & & \\
\hline
\end{tabular}

\footnotetext{
${ }^{a}$ Poorest sandy soils

b Sandy-clayish soils

c Carboniferous substrate soils
} 


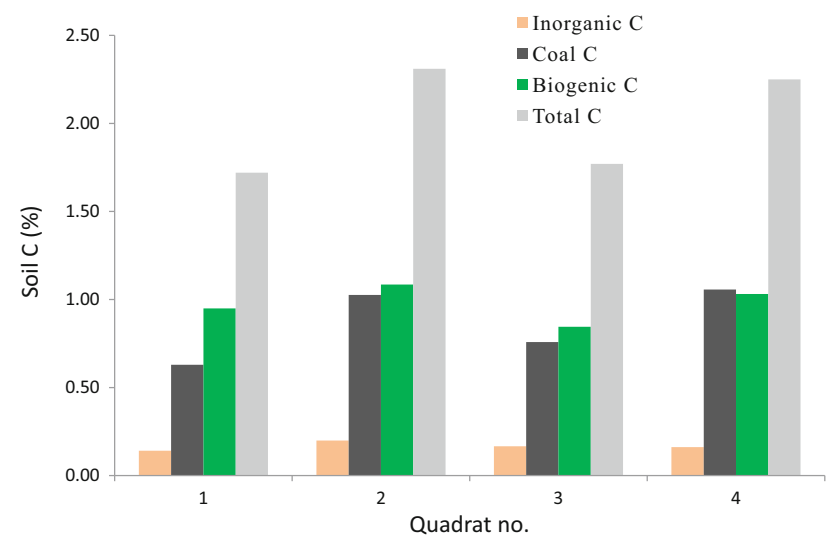

Fig. 11 Distribution of total carbon (\%), inorganic carbon (\%), coal carbon $(\%)$ and biogenic carbon $(\%)$ of different reclaimed mine soil samples

spp) was derived from decomposing plant material. Ussiri and Lal (2008) determined the coal C content of RMS restored with topsoil application using radiocarbon analysis and chemi-thermal method, observed that coal $\mathrm{C}$ accounted for $2 \%$ to $40 \%$ of the total OC in the top $30 \mathrm{~cm}$ soil layer, while in the subsoil (below $30 \mathrm{~cm}$ depth) coal $\mathrm{C}$ accounted up to $92 \%$ of the total organic C. Overall, the reviewed data suggests that the distribution of coal $\mathrm{C}$ in coal-contaminated RMS can be highly variable; therefore, intensive sampling is necessary in order to obtain adequate measure of SOC in restored ecosystems (Ussiri et al. 2014).

\subsection{Total $\mathrm{C}$ stock in reclaimed site and $\mathrm{CO}_{2}$ sequestration}

Total $\mathrm{C}$ stock of the study area was calculated $30.3 \mathrm{Mg} \mathrm{C} \mathrm{ha}^{-1}$.equivalent to $111 \mathrm{Mg} \mathrm{CO}$ sequestered $\mathrm{ha}^{-1}$. Total $\mathrm{C}$ stock in biomass, understorey vegetation and litter and mine soil is given in Fig. 12. In reference forest site, total C stock was estimated as $103 \mathrm{Mg} \mathrm{C}^{-1}$, which is higher than RMS. More than $98 \%$ of C-stock contributed by biomass and soil organic carbon in reference forest site, which is also similar to the RMS. Differences in $\mathrm{C}$ stock between RMS and reference forest site attributed to the biomass C stock. Tripathi et al. (2014) reported total $\mathrm{C}$ sequestration potential of 69.21 Mg C ha ${ }^{-1}$ in 19 years old RMS of Singrauli, India, (equivalent to $253.96 \mathrm{Mg} \mathrm{ha}^{-1}$ capture of atmospheric $\mathrm{CO}_{2}$ and $\mathrm{C}$ sequestration rate of $3.64 \mathrm{Mg} \mathrm{ha}^{-1}$ year $^{-1)}$ which indicates that mine spoil can act as a significant sink for atmospheric $\mathrm{CO}_{2}$ through revegetation. Amichev et al. (2008) estimated total C sequestration (all ecosystem components of RMS of Midwestern and Appalachian coalfields of USA) in pine, hardwood and mixed stands as 148, 117 and $130 \mathrm{Mg} \mathrm{C}^{-1}$ respectively. Another study by Shrestha and Lal (2010) reported total ecosystem C sequestration potential and average rate of RMS (Ohio USA, 25 years age) as $107 \mathrm{Mg} \mathrm{ha}^{-1}\left(5.1 \mathrm{Mg} \mathrm{ha}^{-1}\right.$ year $\left.^{-1}\right)$ and $21 \mathrm{Mg} \mathrm{ha}^{-1}\left(1.0 \mathrm{Mg} \mathrm{ha}^{-1}\right.$ year $\left.^{-1}\right)$ in forest and pasture ecosystems respectively.

\subsection{Future projection of $\mathrm{C}$ stock}

Climate, soil conditions and species composition have major influence on accretion of $\mathrm{C}$ stock in reclaimed mine soil. Similarly, the rate of $\mathrm{C}$ stock accretion for a particular site depends on site characteristics (texture, soil fraction, water holding capacity, bulk density, soil fertility), prevailing climatic conditions and types of species. Vogt et al. (1995) reported 40\%-62\% of total ecosystem C contained in living biomass, and SOM contained $33 \%-50 \%$ of the total. Rate of accumulation of total biomass $\mathrm{C}$ stock was found $3.25 \mathrm{Mg} \mathrm{C} \mathrm{ha}^{-1}$ year $^{-1}$, which is close to the study of Shrestha and Lal (2010) and Singh et al. (2011) and it will take about 17 years to reach the level of $\mathrm{C}$ stock of reference forest site (Table 9). Most noticeable amount of tree $\mathrm{C}$ increased from 5-year stands $\left(0.3 \mathrm{Mg} \mathrm{C}^{-1}\right)$ to 11-year stands (53.8 $\mathrm{Mg} \mathrm{C} \mathrm{ha}^{-1}$ ) (Avera et al. 2015) and decreases gradually. The present rate of accumulation is

Table 8 Contribution of coal C (geogenic C) in total organic carbon (TOC) in the reclaimed coalmine soils

\begin{tabular}{llllll}
\hline Post land use (age) & Age $(\mathrm{yrs})$ & Depth $(\mathrm{cm})$ & Coal C $(\mathrm{g} / \mathrm{kg})$ & Coal C (\% of TOC) & Reference \\
\hline Red Oak & 30 & - & $37-56$ & $25-96$ & Rumpel et al. (1998, 2000) \\
Old Pine & $15-36$ & (O-horizon) & $8-71$ & $79-91$ & Rumpel et al. (2003) \\
Grassland & 28 & - & $0-24.4$ & $0-92$ & Ussiri and Lal (2008) \\
Reclaimed coal mines & $0-22$ & $0-6$ & $0.6-1.76$ & $2.5-14$ & Chaudhuri et al. (2013) \\
Reforested coalmine site & 10 & $0-10$ & 35.97 & 47.4 & Das and Maiti (2016) \\
Unreclaimed (Reference site) & 10 & $10-20$ & 14.4 & 24.2 & 68.5 \\
& & $0-10$ & 36.60 & 55.9 & Present study \\
Reclaimed coal mines & 4 & $10-20$ & 19.15 & 43 &
\end{tabular}


Table 9 Prediction recovery of $\mathrm{C}$ stock (biomass and minesoil) in reclaimed minesoil to reference forest site

\begin{tabular}{|c|c|c|c|c|c|}
\hline Study site & $\begin{array}{l}\text { Total biomass } \mathrm{C} \\
\text { accumulation rate }(\mathrm{Mg} \mathrm{C} \\
\left.\mathrm{ha}^{-1} \text { year }^{-1}\right)\end{array}$ & $\begin{array}{l}\text { Predicted } \\
\text { year }\end{array}$ & $\begin{array}{l}\text { SOC accumulation rate in reclaimed } \\
\text { mine soil }\left(\mathrm{Mg} \mathrm{C} \mathrm{ha}^{-1} \text { year }^{-1}\right)\end{array}$ & $\begin{array}{l}\text { Predicted } \\
\text { year }\end{array}$ & Reference \\
\hline $\begin{array}{l}\text { Reclaimed coal mine, } \\
\text { Singrauli, India }\end{array}$ & $\begin{array}{l}1.658 \\
(0.87-2.34)\end{array}$ & 32 & 1.20 & 16 & $\begin{array}{l}\text { Tripathi et al. (2014 } \\
\text { 2016) }\end{array}$ \\
\hline $\begin{array}{l}\text { Reforested coal mine, } \\
\text { USA }\end{array}$ & $\begin{array}{l}2.5875 \\
(0.50-5.04)\end{array}$ & 20.5 & 1.05 & 18.3 & Avera et al. (2015) \\
\hline $\begin{array}{l}\text { Reclaimed minesoil } \\
\text { (forest), USA }\end{array}$ & 3.365 & 15.8 & 1.52 & 12.6 & $\begin{array}{l}\text { Shrestha and Lal } \\
\quad(2010)\end{array}$ \\
\hline $\begin{array}{l}\text { Reclaimed mine soil, } \\
\text { Poland }\end{array}$ & - & - & 1.45 & 13.2 & $\begin{array}{l}\text { Pietrzykowski and } \\
\text { Krzaklewski } \\
(2010)\end{array}$ \\
\hline $\begin{array}{l}\text { Reclaimed coal mine, } \\
\text { Singrauli, India }\end{array}$ & $\begin{array}{l}3.7075 \\
(2.18-5.65)\end{array}$ & 14.32 & - & - & Singh et al. (2004) \\
\hline $\begin{array}{l}\text { Reclaimed minesoil } \\
\text { (forest), Ohio USA }\end{array}$ & - & - & 1.484 & 13 & $\begin{array}{l}\text { Akala and Lal } \\
\text { (2000) }\end{array}$ \\
\hline $\begin{array}{l}\text { Reclaimed coal mine, } \\
\text { Jharia coalfields, } \\
\text { India }\end{array}$ & 3.25 & 16.4 & $\begin{array}{l}4.08^{\mathrm{a}} \\
1.305^{\mathrm{b}}\end{array}$ & $\begin{array}{l}5^{\mathrm{a}} \\
15\end{array}$ & Present study \\
\hline
\end{tabular}

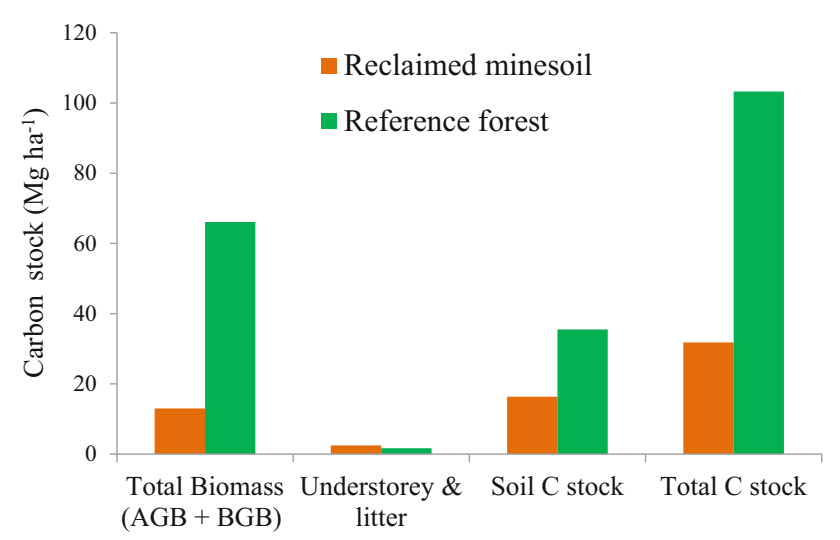

Fig. 12 Comparison of distribution of $\mathrm{C}$ stock (Mg ha-1) in various components of reclaimed coalmine site and reference forest site

much higher than the reported values of 1.658 Mg C ha ${ }^{-1}$ year $^{-1}$ (Singrauli, Tripathi et al. 2014, 2016), which is due to the younger age of site, however, it is expected that, rate of accumulation will decrease with age. Based on rate of SOC accumulation rate, $\mathrm{C}$ stock of RMS will reach close to the level of reference forest site is predicted as 15 years.

Alka and Lal (2001) stated that SOC increased rapidly over the first 20 years following reclamation and then accumulated at lower rates between 20 and 30 years. Based on 0-25 year reclaimed sites chronosequence data, Akla and Lal $(2000,2001)$ predicted that, it may take
100-150 years for SOC stock to reach an equilibrium state in RMS. The accumulation of $\mathrm{C}$ stock will also increase in biomass and minesoil components, with the gradual increase in age of reclamation and this accumulation of $\mathrm{C}$ stock is expected to increase highest in the biomass component. Avera et al. (2015), while studying the chronosequence reforested surface-mined lands in the Central Appalachian Coal Basin (USA) reported that, total ecosystem $\mathrm{C}$ increased from $9.5 \mathrm{Mg} \mathrm{C}^{-1}$ in the 5-year stands to $83.5 \mathrm{Mg} \mathrm{C} \mathrm{ha}^{-1}$ in the 30 -year stands and after 30 years, reforested surface-mined lands contains $47 \%$ of the total $\mathrm{C}$ of the unmined ecosystem $\mathrm{C}\left(179 \mathrm{Mg} \mathrm{C}^{-1}\right)$. Aboveground tree $\mathrm{C}$ was the greatest proportion of ecosystem $\mathrm{C}$, accounting for an average of $73 \%$ of the total ecosystem C. SOC content tripled from the 5-year to the 11-year stands, with the most rapid SOC sequestration rate of $0.7 \pm 0.1 \mathrm{Mg}$ SOC ha ${ }^{-1}$ year $^{-1}$ measured in the 11-year stands. Amichev et al. (2008) reported similar results of at least $75 \%$ of total ecosystem $\mathrm{C}$ contributed by aboveground tree $\mathrm{C}$ on reforested mined land.

Reclamation by development of 3-tier canopy over is better alternative than simple plantation, because it leads to reinstatement of ecosystem in the degraded site. It not only stabilizes and minimizes pollution but also act as potential sink of $\mathrm{CO}_{2}$. Thus, reclaimed coalmine sites can be a viable alternative to sequester carbon both in soil and vegetation and can be useful for combating climate change and global warming issues. The widespread problem of land 
degradation and soil erosion is growing at an exponential rate due to opencast mining activities in agriculture based countries like India, where resources are limited. Concurrently, reclamation of those sites through forestry development approach is a common practice. Interpretation of carbon sequestration will be worthwhile since they can be used to create carbon credits which can be generate significant source of income to fulfill the demands of ever increasing pressure of population.

\section{Conclusions}

Reclamation process is an integral part of mining operation aimed to stabilize mine degraded sites which resulted carbon sequestration. C stock in reclaimed mine soil is dependent on the nature and type of soil and vegetation; age and geoclimatic conditions. Out of total $\mathrm{C}$ stock was $30.3 \mathrm{Mg} \mathrm{C} \mathrm{ha}{ }^{-1}, 43 \%$ is stored in biomass and $53 \%$ as soil organic matter. Coal $\mathrm{C}$ contributes a significant amount of organic carbon in reclaimed mine soils, and for better assessment of $\mathrm{C}$ stock, fractionation study is recommended. Limited field studies data is available on accretion of $\mathrm{C}$ stock in reclaimed minesoil in Indian conditions (only Singrauli and Jharia coalfields) along with very little work of USA and European conditions. Based on the present study, the $\mathrm{C}$ stock will tentatively reach similar to the reference forest site in 17 years, as the rate of carbon accumulation decreases with age. As species composition, climate conditions and nature of mine soils is site specific, this study will a guidelines for a specific geo-climatic conditions.

\section{Compliance with ethical standards}

Conflict of interest The authors declare no conflict of interest in any concern or context in the present study.

Ethical standards All the experiments are conducted in this study following local, national or international guidelines and comply with the current laws of the country, India. No permission or license was required for the study.

Open Access This article is distributed under the terms of the Creative Commons Attribution 4.0 International License (http://crea tivecommons.org/licenses/by/4.0/), which permits unrestricted use, distribution, and reproduction in any medium, provided you give appropriate credit to the original author(s) and the source, provide a link to the Creative Commons license, and indicate if changes were made.

\section{References}

Ahirwal J, Maiti SK (2016) Assessment of soil properties of different land uses generated due to surface coal mining activities in tropical Sal (Shorea robusta) forest, India. Catena 140:155-163
Akala VA, Lal R (2000) Potential of mine land reclamation for soil organic carbon sequestration in Ohio. Land Degrad Dev 11(3):289-297

Akala VA, Lal R (2001) Soil organic carbon pools and sequestration rates in reclaimed minesoils in Ohio. $\mathrm{J}$ Environ Qual 30(6):2098-2104

Amichev BY, Burger JA, Rodrigue JA (2008) Carbon sequestration by forests and soils on mined land in the Midwestern and Appalachian coalfields of the US. Forest Ecol Manag 256(11):1949-1959

Andrews SS, Karlen DL, Mitchell JP (2002) A comparison of soil quality indexing methods for vegetable production systems in Northern California. Agric Ecosyst Environ 90:25-45

Avera BN, Strahm BD, Burger JA, Zipper CE (2015) Development of ecosystem structure and function on reforested surface-mined lands in the Central Appalachian Coal Basin of the United States. New For 46(5-6):683-702

Barnshiel RL, Hower JM (1997) Coal surface mine reclamation in the eastern United States: the revegetation of disturbed lands to hayland/pasture or cropland. Adv Agron 61:233-275

Bi Y, Zhang Y (2014) Role of the different planting age of seabuckthorn forests to soil amelioration in coal mining subsidence land. Int J Coal Sci Technol 1(2):192-197

Bray R, Kurtz LT (1966) Determination of total, organic and available forms of phosphorus in soil. Soil Sci 59:39-45

Brown S (1997) Estimating biomass and biomass change of tropical forests: a primer, vol 134). Food and Agriculture Organization (FAO) of the United Nations, Rome

Brown S, Gillespie AJ, Lugo AE (1989) Biomass estimation methods for tropical forests with applications to forest inventory data. For Sci 35(4):881-902

Burger JA (2004) Restoring forests on mined land in the Appalachians: results and outcomes of a 20-year research program. In: Barnhisel RI (ed) Proceedings of a joint conference of American Society of Mining and Reclamation. 21 ${ }^{\text {st }}$ annual national conference, 25th West Virginia surface mine drainage task force symposium Morgantown, WV, p 260

Cairns MA, Brown S, Helmer EH, Baumgardner GA (1997) Root biomass allocation in the world's upland forests. Oecologia 111:1-11

Chabbi A, Rumpel C, Grootes PM, Mariotti A, Huttl RF (2006) Isotopic tracers for theanalysis of vegetation-derived organic matter in lignite-containing soils and sediments along a transect ranging from a forest soil to submerged lake sediment. Org Geochem 37:740-753

Chandra D (1992) Jharia coalfield. Geological Society of India, Bangalore, pp 1-11

Chaudhuri S, McDonald LM, Pena-Yewtukhiw EM, Skousen J, Roy M (2013) Chemically stabilized soil organic carbon fractions in a reclaimed minesoil chronosequence: implications for soil carbon sequestration. Environ Earth Sci 70(4):1689-1698

Coppin NJ, Bradshaw AD (1982) Quarry reclamation. Mining Journal Books, London, pp 8-17

Dar JA, Sundarapandian S (2015) Variation of biomass and carbon pools with forest type in temperate forests of Kashmir Himalaya, India. Environ Monit Asses 187(2):1-7

Das R, Maiti SK (2016) Importance of Carbon Fractionation for the estimation of Carbon sequestration in Reclaimed Coalmine soils-a case study from Jharia Coalfields, Jharkhand, India. Ecol Eng 90:135-140

Dudley NS, Fownes JH (1992) Preliminary biomass equations for eight species of fast-growing tropical trees. J Trop For Sci 5(1):68-73

Dutta RK, Agrawal M (2003) Restoration of opencast coal mine spoil by planting exotic tree species: a case study in dry tropical region. Ecol Eng 21(2):143-151 
Haering C, Daniels WL, Roberts JA (1993) Changes in mine soil properties resulting from overburden weathering. J Environ Qual 22:194-200

IPCC (2000) Special report on land use, land use change, and forestry, summary for policy makers. Intergovernmental Panel on Climate Change, Cambridge University Press, Cambridge

IPCC (2006) IPCC Guidelines for national greenhouse gas inventories. Intergovernmental Panel on Climate Change, NGGIP Publications, IGES, Japan

Jacinthe PA, Lal R, Ebinger M (2004) Carbon sequestration in reclaimed mined lands. In: Proceedings of the second annual carbon sequestration conference, 5-8 May, Alexandria, VA

Jha KK (2015) Carbon storage and sequestration rate assessment and allometric model development in young teak plantations of tropical moist deciduous forest, India. J For Res 26(3):589-604

Johnson CD, Skousen JG (1995) Minesoil properties of 15 abandoned mine landsites in West Virginia. J Environ Qual 24:635-643

Kanime N, Kaushal R, Tewari SK, Raverkar KP, Chaturvedi S, Chaturvedi OP (2013) Biomass production and carbon sequestration in different tree-based systems of Central Himalayan Tarai region. For Trees Livelihoods 22(1):38-50

Karu H, Szava-Kovats R, Pensa M, Kull O (2009) Carbon sequestration in a chronosequence of Scots pine stands in a reclaimed opencast oil shale mine. Can J For Res 39(8):1507-1517

Kumar S, Maiti SK, Chaudhuri S (2015) Soil development in 2-21 years old coalmine reclaimed spoil with trees: a case study from Sonepur Bazari opencast project, Raniganj Coalfield, India. Ecol Eng 84:311-324

Lal R (2004) Soil carbon sequestration impacts on global climate change and food security. Science 204:1623-1627

Lal R (2005) World crop residues production and implication of its use as a biofuel. Environ Int 31:575-586

Lal R, Bruce JP (1999) The potential of world cropland soils to sequester $\mathrm{C}$ and mitigate the greenhouse effect. Environ Sci Policy 2:177-185

Lal R, Kimble JM, Follett RF (1998) Land use and soil C pools in terrestrial ecosystems. In: Lal R, Kimble JM, Follett RF (eds) Management of carbon sequestration in soil. CRC Lewis Publisher, Boca Raton, pp 1-10

Lodhiyal N, Lodhiyal LS (2003) Biomass and net primary productivity of Bhabar Shisham forests in central Himalaya, India. For Ecol Manag 76(1):217-235

Lodhiyal N, Lodhiyal LS, Pangtey YPS (2002) Structure and function of Shisham forests in Central Himalaya, India: dry matter dynamics. Ann Bot 89(1):41-54

Lonsdale WM (1988) Predicting the amount of litterfall in forests of the world. Ann Bot 61(3):319-324

MacDicken KG (1997) A guide to monitoring carbon storage in forestry and agroforestry projects. Winrock Int Institute for Agricultural Development, Arlington, p 87

Maharaj S, Barton CD, Karathanasis TA, Rowe HD, Rimmer SM (2007) Distinguishing" new" from" old" organic carbon in reclaimed coal mine sites using thermogravimetry: II. Field validation. Soil Sci 172(4):302-312

Maiti SK (2006) Properties of minesoil and its affects on bioaccumulation of metals in tree species: a case study from a large opencast coalmining project. Int $\mathrm{J}$ Min Reclamat Environ 20(2):96-110

Maiti SK (2007) Bioreclamation of coalmine overburden dumpswith special emphasis on micronutrients and heavy metals accumulation in tree species. Environ Monit Assess 125:111-122

Maiti SK (2013) Ecorestoration of the coalmine degraded lands. Springer, New York
Maiti SK, Ghose MK (2005) Ecorestoration of acidic coalmine overburden dumps- an Indian case studies. Land Contam Reclamat 13(4):361-369

Maiti SK, Maiti D (2015) Ecological restoration of waste dumps by topsoil blanketing, coir-mating and seeding with grass-legume mixture. Ecol Eng 77:74-84

Maiti SK, Saxena NC (1998) Biological reclamation of coalmine spoils without topsoil: an amendment study with domestic raw sewage and grass-legumes mixture. Int J Surf Min Reclamat Environ 12:87-90

Maiti SK, Shee C, Ghose MK (2007) Selection of plant species for the reclamation of mine degraded land in the Indian context. Land Contam Reclamat 15(1):55-66

McLean EO (1982) Soil pH and lime requirement. In: Page AL et al (eds) Methods of Soil Analysis, Part 2, 2nd edn. ASA and SSSA, Madison, pp 199-224

Mukhopadhyay S, Maiti SK (2011) Trace metal accumulation and natural mycorrhizal colonisation in an afforested coalmine overburden dump- a case study from India. Int J Min Reclamat Environ 25(2):187-207

Mukhopadhyay S, Maiti SK (2014) Soil $\mathrm{CO}_{2}$ flux in grassland, afforested land and reclaimed coalmine overburden dumps: a case study. Land Degrad Dev 25(3):216-227

Mukhopadhyay S, Maiti SK, Masto RE (2013) Use of reclaimed mine soil index (RMSI) for screening of tree species for reclamation of coal mine degraded land. Ecol Eng 57:133-142

Mukhopadhyay S, Maiti SK, Masto RE (2014) Development of mine soil quality index (MSQI) for evaluation of reclamation success: a chronosequence study. Ecol Eng 71:10-20

Nelson DW, Sommers LE (1996) Total carbon, organic carbon, and organic matter. Methods of soil analysis, Part 3(3):961-1010

Pietrzykowski M, Daniels WL (2014) Estimation of carbon sequestration by pine (Pinus sylvestris L.) ecosystems developed on reforested post-mining sites in Poland on differing mine soil substrates. Ecol Eng 73:209-218

Pietrzykowski M, Krzaklewski W (2010) Potential for carbon sequestration in reclaimed mine soil on reforested surface mining areas in Poland. Nat Sci 2(9):1015-1021

Post WM, Kwon KC (2000) Soil carbon sequestration and landuse change: processes and potential. Glob Change Biol 6(3):317-328

Pragasan LA, Parthasarathy N (2005) Litter production in tropical dry evergreen forests of south India in relation to season, plant lifeforms and physiognomic groups. Curr Sci 88(8):125-126

Rao KS, Ramakrishnan PS (1989) Role of bamboos in nutrient conservation during secondary succession following slash and burn agriculture (Jhum) in North-East India. J Appl Ecol 26:625-633

Rumpel C, Knicker H, Kogel-Knabner I, Skjemstad JO, Huttl RF (1998) Types and chemical composition of organic matter in reforested lignite-rich mine soils. Geoderma 86:123-142

Rumpel C, Skjemstad JO, Knicker H, Kogel-Knabner I, Huttl RF (2000) Techniques for the differentiation of carbon types present in lignite-rich mine soils. Org Geochem 31:543-551

Rumpel C, Balesdent J, Grootes P, Weber E, Kogel-Knabner I (2003) Quantification of lignite- and vegetation-derived soil carbon using ${ }^{14} \mathrm{C}$ activity measurements in a forested chronosequence. Geoderma 112:155-166

Schlesinger WH, Bernhardt ES (2013) Biogeochemistry: An analysis of global change. Academic Press Inc., San Diego

Schmidt MWI, Knicker H, Hatcher PG, KogelKnabner I (1996) Impact of brown coal dust on the organic matter in particle-size fractions of a Mollisol. Org Geochem 25:29-39

Shrestha RK, Lal R (2006) Ecosystem carbon budgeting and soil carbon sequestration in reclaimed mine soil. Environ Int 32:781-796 
Shrestha RK, Lal R (2010) Carbon and nitrogen pools in reclaimed land under forest and pasture ecosystems in Ohio, USA. Geoderma 157(3):196-205

Singh AN, Raghubanshi AS, Singh JS (2004) Comparative performance and restoration potential of two Albizia species planted on mine spoil in a dry tropical region, India. Ecol Eng. 22(2): 123-140

Singh L, Singh JS (1991) Species structure, dry matter dynamics and carbon flux of a dry tropical forest in India. Ann Bot 68:263-273

Singh S, Singh JS (1995) Microbial biomass association with waterstable aggregates in forest, savanna and cropland soils of a seasonally dry tropical region, India. Soil Biol Biochem 27:1027-1033

Singh AN, Singh JS (1999) Biomass net primary production and impact of bamboo plantation on soil redevelopment in a dry tropical region. For Ecol Manag 119(1):195-207

Singh V, Tewari A, Kushwaha SP, Dadhwal VK (2011) Formulating allometric equations for estimating biomass and carbon stock in small diameter trees. For Ecol Manag 261(11):1945-1949

Skousen J, Zipper CE (2014) Post-mining policies and practices in the Eastern USA coal region. Int J Coal Sci Technol 1(2):135-151

Sperow M (2006) Carbon sequestration potential in reclaimed mine sites in seven East- Central states. J Environ Qual 35(4):1428-1438

Stahl PD, Wick AF, Ganjegunte G, Norton U, Ingram LJ (2009) Redevelopment of soil carbon pools on reclaimed surface mine lands. In: Barnhisel RI (ed) Revitalizing the environment: proven solutions and innovative approaches. ASMR, Lexington, pp 1348-1370

Subbiah BV, Asija GL (1956) A rapid procedure for the determination of available nitrogen in soils. Curr Sci 25:259-260

Terakunpisut J, Gajaseni N, Ruankawe N (2007) Carbon sequestration potential in aboveground biomass of Thong Pha Phum National Forest, Thailand. Appl Ecol Environ Res 5(2):93-102
Thurman NC, Sencindiver JC (1986) Properties, classification and interpretation of minesoils at two sites in Western Virginia. Soil Sci Soc Am J 50:181-185

Tripathi SK, Singh KP (1996) Culm recruitment, dry matter dynamics and carbon flux in recently harvested and mature bamboo savannas in the Indian dry tropics. Ecol Res 11:149-164

Tripathi N, Singh RS, Nathanail CP (2014) Mine spoil acts as a sink of carbon dioxide in Indian dry tropical environment. Sci Total Environ 468:1162-1171

Tripathi N, Singh RS, Hills CD (2016) Soil carbon development in rejuvenated Indian coal mine spoil. Ecol Eng 90:482-490

Ussiri DAN, Lal R (2005) Carbon sequestration in reclaimed minesoils. Cr Rev Plant Sci 24:151-165

Ussiri DAN, Lal R (2008) Method for determining coal carbon in the reclaimed minesoils contaminated with coal. Soil Sci Soc Am J 72(1):231-237

Ussiri DAN, Jacinthe PA, Lal R (2014) Methods for determination of coal carbon in reclaimed minesoils: a review. Geoderma 214:155-167

Vogt KA, Vogt DJ, Brown S, Tilley JP, Edmonds RL, Silver WL, Siccama T (1995) Dynamics of forest floor and soil organic matter accumulation boreal, temperate, and tropical forests. In: Lal R, Kimble J, Levine E, Stewart BA (eds) Soil management and greenhouse effect. CRC Lewis Publishers, Boca Raton, pp 159-175

Xiao W, Hu Z, Fu Y (2014) Zoning of land reclamation in coal mining area and new progresses for the part 10 years. Int $\mathrm{J}$ Coal Sci Technol 1(2):177-183

Zipper CE, Burger JA, Skousen JG, Angel PN, Barton CD, Davis V, Franklin JA (2011) Restoring forests and associated ecosystem services on Appalachian coal surface mines. Environ Manag $47: 751-765$ 